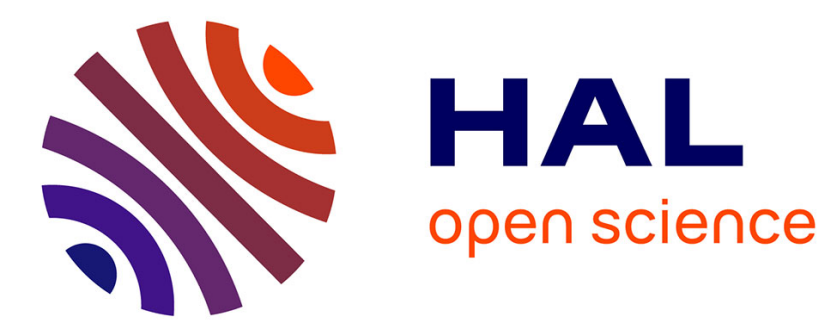

\title{
Does trade liberalization trigger tax competition? Theory and evidence from OECD countries
}

Nelly Exbrayat

\section{To cite this version:}

Nelly Exbrayat. Does trade liberalization trigger tax competition? Theory and evidence from OECD countries. 2016. halshs-01328769

\section{HAL Id: halshs-01328769 \\ https://shs.hal.science/halshs-01328769}

Preprint submitted on 8 Jun 2016

HAL is a multi-disciplinary open access archive for the deposit and dissemination of scientific research documents, whether they are published or not. The documents may come from teaching and research institutions in France or abroad, or from public or private research centers.
L'archive ouverte pluridisciplinaire HAL, est destinée au dépôt et à la diffusion de documents scientifiques de niveau recherche, publiés ou non, émanant des établissements d'enseignement et de recherche français ou étrangers, des laboratoires publics ou privés. 
UMR 5824

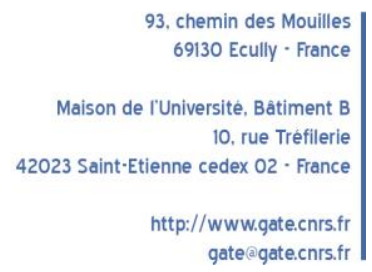

WP 1620 - June 2016

\title{
Does trade liberalization trigger tax competition? Theory and evidence from OECD countries
}

Nelly Exbrayat

\begin{abstract}
:
This article aims at assessing the empirical relevance of New Economic Geography models of tax competition. We rely on a simple model to specify tax reactions functions, which we estimate with a panel covering (up to) 26 OECD countries over the period 1982 to 2006. We provide striking support for the two main predictions regarding the slope and the constant of the reaction function: national governments seem to adjust their corporate tax rate towards the level chosen in countries that are more populated, and they tend to set higher corporate tax rates when their country enjoys a high real market potential. Through the latter effect, trade integration exerts a positive influence on the level of corporate taxation. However, using a theoretically grounded index of bilateral trade integration, we also show that trade liberalization gives rise to significant tax interactions in the setting of effective average tax rates in the case of European countries, thus exerting a downward pressure on corporate tax rates.
\end{abstract}

\section{Keywords:}

Tax competition, new economic geography, panel data, trade integration, market potential

\section{JEL codes:}

$\mathrm{H} 2, \mathrm{H} 3, \mathrm{C} 23, \mathrm{~F} 12$

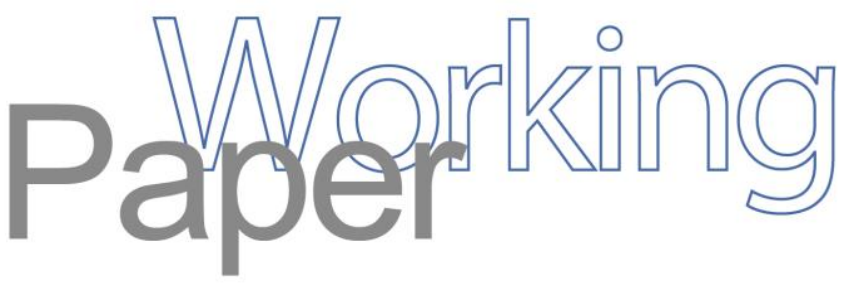




\title{
Does trade liberalization trigger tax competition?
}

\section{Theory and evidence from OECD countries*}

\author{
Nelly Exbrayat ${ }^{\dagger}$
}

\begin{abstract}
This article aims at assessing the empirical relevance of New Economic Geography models of tax competition. We rely on a simple model to specify tax reactions functions, which we estimate with a panel covering (up to) 26 OECD countries over the period 1982 to 2006. We provide striking support for the two main predictions regarding the slope and the constant of the reaction function: national governments seem to adjust their corporate tax rate towards the level chosen in countries that are more populated, and they tend to set higher corporate tax rates when their country enjoys a high real market potential. Through the latter effect, trade integration exerts a positive influence on the level of corporate taxation. However, using a theoretically grounded index of bilateral trade integration, we also show that trade liberalization gives rise to significant tax interactions in the setting of effective average tax rates in the case of European countries, thus exerting a downward pressure on corporate tax rates.
\end{abstract}

Keywords: Tax competition, new economic geography, panel data, trade integration, market potential.

JEL classification: H2, H3, C23, F12

\footnotetext{
* This paper is a shortened version of a chapter from my dissertation. I am grateful to my supervisor, Stéphane Riou, for his help and advice. For valuable comments and discussion I am also grateful to Aurélie Cassette, Pierre-Philippe Combes, Ron Davies, Benny Geys and Sonia Paty, as well as participants at the VIIIth RIEF Doctoral Meetings in Barcelona, the 1st workshop 'Economie et Espace' in Lille, the WZB seminar in Berlin, the workshop 'Frontiers in Public Finance' in Munich, the French conference of spatial econometrics in Besançon, and the world conference of spatial econometrics in Barcelona. This work was supported by the German Science Foundation (DFG) and the French Research Agency (ANR) through the grant 'Competition among Nation States' [KO 1437/9-1].

† Univ. Lyon, UJM Saint-Etienne, CNRS, GATE L-SE UMR 5824, F-42023 Saint-Etienne, France. E-mail: Nelly.Exbrayat@univ-st-etienne.fr. Address: GATE Lyon Saint-Etienne, 10, Rue Tréfilerie, Bâtiment B, 42023 Saint-Etienne cedex 02, France. Phone: +33(0)4-77-42-19-69. Fax +33(0)4-77-42-19-50.
} 


\section{Introduction}

According to the seminal models of tax competition (Zodrow and Mieszkowski, 1986; Wilson, 1991; Bucovetsky, 1991), capital mobility leads governments to strategically decrease their capital tax in order to prevent their country from suffering large capital outflows. Empirical research has generally been supportive of this proposition, both when analysing the sensitivity of firms' location choices to fiscal policy, as well as fiscal interactions between governments. For example, comparing the results of 25 empirical studies on the sensitivity of foreign direct investment to corporate taxation, De Mooij and Ederveen (2003) estimate the median value of the tax base elasticity to be -3.3 . Moreover, tax rates across countries exhibit significant positive spatial dependence, suggesting the presence of strategic interactions among governments (e.g., Devereux et al., 2008; Overesch and Rincke, 2009; Cassette and Paty, 2008; Redoano, 2014).

More recently, models using a New Economic Geography (NEG) framework show that the intensity of tax competition depends in fine on the level of trade integration, through its impact on the sensitivity of capital flows to fiscal policies. More precisely, the relationship between corporate taxation and trade integration is non-monotonous (Ludema and Wooton, 2000; Andersson and Forslid, 2003; Baldwin and Krugman, 2004; Ottaviano and Van Ypersele, 2005). Unfortunately, almost all empirical studies on international tax competition implicitly refer to the standard tax competition literature, according to which firms are perfectly competitive and there are no frictions to trade (Devereux et al., 2008; Cassette and Paty, 2008). An exception is the empirical study by Davies and Voget (2011) on corporate tax interactions in the European Union. Building on a stylised model of tax competition between three countries, they show that firm location strategy is driven by the relative level of after-tax market potential. Therefore, assuming that governments seek to maximise corporate tax revenues, the tax level in one country is more sensitive to that of countries where firms enjoy a higher market potential. Davies and Voget (2011) provide empirical evidence for this finding and show that governments respond more to taxes set in EU countries as compared to non-EU countries, suggesting that European enlargement might exacerbate tax competition. However, none of these studies investigate the specific - and ambiguous - impact of trade integration on taxes. A first contribution this paper makes to the literature is to translate the NEG framework into an empirical model that allows us to determine how trade integration affects tax competition. This is important as it provides the tools to evaluate, for example, whether further trade integration among OECD countries would exacerbate or dampen tax competition.

Our second contribution likewise follows from the use of NEG models of tax competition. Unlike most previous empirical papers - which define links between countries in an ad hoc manner (for an exception, see Davies and Voget, 2011) - we set up a model of tax competition characterized by imperfect trade integration, increasing returns to scale and asymmetric market sizes, from which we explicitly derive the tax reaction function. In such a framework, the existence of agglomeration economies carries two implications regarding the slope and the constant of the tax reaction function: tax interactions are stronger for the less 
populated country, and the constant of the reaction function is increasing with the number of firms that a country would attract in a world without public policies. Indeed, the tax base elasticity is lower in the bigger country that benefits from a higher market potential, so that the government can tax agglomeration economies. Our empirical approach then consists of estimating this tax reaction function with a panel covering (up to) 26 OECD countries over the period 1982 to 2006. Specifically, we test (a) whether tax interdependencies are linked to the relative size of countries and the level of trade integration (by using a theoretically grounded index of bilateral trade integration), and (b) whether market potential positively affects corporate tax rates. Note that the latter tests whether further trade liberalization, by improving the market potential of countries, allows governments to raise taxes (through the constant of the reaction function), whereas the former tests whether it contributes to the decline of corporate taxes by fostering tax interactions (through the slope of the reaction function).

The paper proceeds as follows. We start in section 2 with a brief description of the model and present the tax reaction function that will be tested. The empirical specification is described in section 3. Our results and robustness checks are described in section 4. The results broadly support the theoretical prediction regarding the constant of the tax reaction function. The real market potential exerts a positive and very significant impact on effective average tax rate or statutory tax rates. The empirical evidence regarding the slope of the reaction function depends on the weighting schemes. We provide clear evidence that national governments significantly react to a cut in corporate taxation in the most populated countries of the sample. The empirical evidence regarding the influence of trade integration on tax interactions is less clear-cut. Our findings reveal that bilateral trade integration gives rise to significant interactions with respect to effective average tax rates when we consider a subsample of European countries. Therefore, in the case of European countries, we provide empirical evidence for the ambiguous impact of trade integration on corporate taxes in European countries. On the one hand, the decline in trade costs strengthens tax interactions and contributes to a race-to-the-bottom in corporate taxes. On the other hand, trade integration improves the real market potential of countries and thus allows government to set a higher corporate tax irrespective of the tax policy in the other countries. Importantly, we further investigate the mechanism driving tax interactions by allowing the coefficient on tax interactions to vary depending on the degree of capital mobility in countries. Our findings reveal that when using relative population weights, a country adjusts its tax rate to the average level in the other countries only if those countries are characterized by an equal or higher degree of capital mobility. In the case of trade integration weights, the evidence shows that strategic interactions only prevail between countries that are characterized by a high degree of capital mobility. This suggests that the willingness to attract firms (or to avoid their relocation abroad) might well be a relevant explanation for the existence of interdependencies in corporate taxes at the international level. The final section concludes.

\section{Theoretical background}

We consider economic geography models with mobile physical capital and immobile labour, 
which are the most relevant when it comes to international tax competition given the low mobility of labour across countries. In particular, we use the model of Ottaviano and Van Ypersele (2005), which we simplify, without loss of generality, by assuming oligopolistic rather than monopolistic competition.

The economy consists of two large countries $i=1,2$ of possibly different sizes but identical technology. There are two factors of production, physical capital and labour, whose total endowments are denoted by $K$ and $L$, respectively. Total factor endowments are equally distributed across individuals. However, we assume that a share $\sigma_{i}$ of the total population lives in country $i$, with $\sigma_{1}>1 / 2$. While these workers are immobile, they can invest their capital wherever they want.

The private sector consists of a modern industry and a traditional one. Each industrial firm produces a homogeneous product under increasing returns to scale and Cournot competition. By contrast, firms in the traditional sector produce a numéraire good under constant returns to scale, using labour as the only input. The public sector in each country is represented by a benevolent government, which imposes a lump-sum tax $\tau_{i}$ on capital invested in its country. If this tax is positive, the resulting tax revenues $T_{i}$ are redistributed in a lump-sum way to the workers, while if a government subsidizes capital these expenditures are financed through lump-sum taxation of workers.

\subsection{Consumption}

Consumers in both countries share the same quasi-linear utility function:

$$
u_{i}=a x_{i}-\frac{\beta}{2} x_{i}^{2}+z_{i}
$$

where $x_{i}$ denotes the individual consumption of the industrial good and $z_{i}$ the consumption of the numéraire.

Every resident in the economy supplies one unit of labour and $K / L$ units of capital. The wage rate in each country is determined in the numéraire industry, which uses labour as the only input. Free trade in the numéraire thus equalizes the wage across countries as $w$. Moreover, each resident receives income from capital at the world net return to capital, denoted by $r$. Thus, the budget constraint for a representative consumer in country $i$ is given by:

$$
w+r \frac{K}{L}+\frac{T_{i}}{\sigma_{i} L}=z_{i}+p_{i} x_{i}
$$

where $p_{i}$ denotes the price of good $x$ in country $i$.

Given (1) and (2), the individual demand for the manufactured good in country $i$ is given by $x_{i}=\left(a-p_{i}\right) / \beta$ so that the total demand for this good in each country is:

$$
X_{i}=\sigma_{i} L \frac{a-p_{i}}{\beta}
$$

\subsection{Firms}

Firms in the manufacturing sector produce a homogeneous good under increasing returns to scale and Cournot competition. The production of the manufactured good requires a fixed 
amount of one capital unit and each unit of output requires one unit of labour. Moreover, good $x$ is traded at a cost of $c$ units of the numéraire per unit shipped between the two countries, which raises the marginal cost of serving the foreign market to $(w+c){ }^{1}$

Firms are able to segment their markets by choosing the quantities to sell on the domestic and the foreign market independently. Therefore, the total gross profit of each firm in country $i$ is given by:

$$
\Pi_{i}=\left(p_{i}-w\right) x_{i i}+\left(p_{j}-w-c\right) x_{i j}
$$

where $x_{i j}$ denotes sales in country $j$. Maximizing profits taking into account demand yields the following output levels for a firm located in a country $i$ :

$$
x_{i i}=\frac{\sigma_{i} L}{\beta} \frac{a-w+c K \lambda_{j}}{K+1} ; \quad x_{i j}=\frac{\left(1-\sigma_{i}\right) L}{\beta} \frac{a-w-c\left(K \lambda_{j}+1\right)}{K+1}
$$

where $\lambda_{j}$ stands for the share of capital invested in country $j$. Intuitively, everything else equal, an exporter sells less in a market than an indigenous rival $\left(x_{j i}<x_{i i}\right)$ because of trade costs, and we focus on the cases where the trade cost is low enough to ensure that $x_{j i}$ and $x_{i j}$ are positive.

The resulting equilibrium price in country $i$ is the following:

$$
p_{i}=\frac{a+c K \lambda_{j}+w K}{K+1} .
$$

Observe that the consumer price level increases with trade barriers because the local firms are more protected against foreign competition, but decreases with the number of firms located in this country because of a competition effect that is declining as trade costs fall.

Inserting these equilibrium prices in (4) yields the following operating profits in the short-run:

$$
\Pi_{i}^{*}=\frac{\sigma_{i} L}{\beta}\left(\frac{a-w+c K \lambda_{j}}{K+1}\right)^{2}+\frac{\left(1-\sigma_{i}\right) L}{\beta}\left(\frac{a-w-c\left(K \lambda_{j}+1\right)}{K+1}\right)^{2}
$$

In the long-run, net profits are equal to zero in equilibrium due to free entry and exit. Thus, the equilibrium rental rate is determined by a bidding process for capital, which ends when no firm can earn a strictly positive profit at the equilibrium market price, that is:

$$
r_{i}=\Pi_{i}^{*}-\tau_{i}
$$

The location equilibrium of capital can now be found by solving the arbitrage condition according to which no unit of capital can induce a higher net return by being invested in another country, that is, when $\Pi_{i}^{*}-\tau_{i}=\Pi_{j}^{*}-\tau_{j}=r$. The resulting share of capital invested in a country $i$ is given by:

$$
\lambda_{i}=\underbrace{\frac{1}{2}+\left(\sigma_{i}-\frac{1}{2}\right) \frac{2 a-2 w-c}{K c}}_{\lambda_{i}^{M}}-\underbrace{\frac{K+1}{2 K L c^{2}} \beta}_{\epsilon}\left(\tau_{i}-\tau_{j}\right)
$$

where $2 a-2 w-c>0$ under the trade condition.

We first analyse the term $\lambda_{i}^{M}$, which stands for the share of mobile firms located in a country when governments do not rely on their public policies to attract them. There are two

\footnotetext{
1 The term 'trade costs' must be understood in a general sense, as including non-tariff barriers and transportation costs.
} 
main mechanisms driving the location of firms: one agglomeration force due to the advantage of being near demand which is increasing with trade integration $\left(d \lambda_{i}^{M} / d \sigma_{i}>0\right.$ and $d^{2} \lambda_{i}^{M} / d \sigma_{i} d c<0$ ) (a reminiscent of the 'market potential effect'), and one dispersion force due to the proximity of competitors ('market crowding effect'). When trade is costly and countries have different sizes, the market potential effect does more than compensate the market crowding effect so that the country with a larger demand for the increasing-returns industry attracts an even larger share of the production.

Now let us analyse how tax policies affect the location of firms. When capital is taxed according to the source principle, a unilateral increase in country $i$ 's tax rate or a decrease in the other country's tax rate generates a capital outflow from country $i\left(d \lambda_{i}^{M} / d \tau_{i}=-\epsilon<0\right)$ : this is the so-called tax base erosion effect.

Interestingly, the two components of eq. (5) encapsulate the opposite effects that trade integration might exert on the attractiveness of countries, and thus on the government's behaviour. On the one hand, as trade costs decrease, the location of capital becomes relatively more responsive to the tax policies than it is to the market forces ( $\epsilon$ increases) so that more capital is attracted to the low-tax country. On the other hand, as trade gets freer, everything else being equal, it becomes more profitable to serve the small market through export. Trade integration thus improves the attractiveness of the largest country thanks to agglomeration economies, and this will allow its government to raise taxes without suffering from a large capital outflow. Importantly, there is a trade cost threshold under which it becomes so cheap to serve the foreign market through exports that a core-periphery structure emerges, characterized by the complete concentration of manufacturing firms in the biggest country where the tax base elasticity is equal to zero. In what follows, we ignore the latter possibility because we test predictions of the model on a dataset in which even the less industrialized countries attract manufacturing firms. ${ }^{2}$

\subsection{Tax competition}

We assume that each government is benevolent. Inserting the budget constraint in the national welfare function, we get the following objective function for government of country $i$ :

$$
W_{i}=\sigma_{i} L S_{i}\left(\lambda_{i}\right)+T_{i}\left(\lambda_{i}\right)+\sigma_{i} \operatorname{Kr}\left(\lambda_{i}\right)+\text { constant }
$$

where $S_{i}=\left(a-p_{i}\right)^{2} / 2 \beta$ denotes the consumer's surplus, $T_{i}=\tau_{i} \lambda_{i} K$ stands for the tax revenues redistributed to residents if $T_{i}>0$ (or the total taxes paid by them if $T_{i}<0$ ), and $\sigma_{i} \operatorname{Kr}\left(\lambda_{i}\right)$ is the income from capital ownership.

In the extreme case where all firms are clustered in a country, the tax base elasticity is equal to zero and the complete agglomeration of firms creates rents that can be taxed away by the government without inducing capital outflow. ${ }^{3}$ As pointed out by Hünerbein and Seidel

\footnotetext{
${ }^{2}$ Even though this is an imperfect indicator, note that in our sample the share of industry in the GDP is always higher than 20\%. More importantly, the 'new' EU member states - which are often considered as peripheral countries (at least during the time period considered in our empirical study) - succeed in attracting FDI from western countries, for example in the car industry. Therefore, our dataset does not include the kind of coreperiphery pattern predicted by New Economic Geography models.

${ }^{3}$ Therefore, there are no tax interactions. The tax outcome is such that the tax differential between both countries
} 
(2010), the downward trend in corporate taxes casts doubt on the existence of such a taxable agglomeration 'rent'. The explanation provided in their model is that intra-regional tax competition within core countries could make it impossible to tax the agglomeration rent. Here, we analyze another possibility. We consider that agglomeration economies are not strong enough to give rise to a core-periphery pattern. This implies that governments consider that the tax base elasticity is always negative, and that it varies across countries depending on their relative attractiveness.

Considering such a scenario of partial agglomeration, the maximisation of the objective function with respect to $t_{i}$ gives the following first-order condition:

$$
\frac{d W_{i}}{d \tau_{i}}=\underbrace{\sigma_{i} L \frac{d S_{i}}{d \lambda_{i}} \frac{d \lambda_{i}}{d \tau_{i}}}_{\text {consumer surplus effect (-) }}+\underbrace{\lambda_{i} K+\tau_{i} K \frac{d \lambda_{i}}{d \tau_{i}}}_{\text {tax revenue effect (+/-) }}+\underbrace{\sigma_{i} K \frac{d r}{d \tau_{i}}}_{\text {capital income effect (+/-) }}=0
$$

Clearly, the consumer's surplus effect is negative: governments have an incentive to cut capital taxes in order to attract firms so that competition becomes fiercer in the country and the price level falls, making consumers better off. The two other effects are ambiguous. The tax revenue effect provides governments with an incentive to increase capital taxation provided that the tax base elasticity is lower than one in absolute value. Following a tax rise, the capital income effect also goes in two opposite directions: the induced outflow of capital reduces competition on the goods market and thus raises the gross return to capital, whereas, for a given amount of capital, a tax rise has a direct negative effect on the net return to capital.

Interestingly, each of these incentives to tax can be expressed as a function of the level of taxes in each country and the amount of capital invested in the country at the free-market equilibrium. Indeed, we can rewrite the first-order condition as follows:

$$
\frac{d W_{i}}{d \tau_{i}}=-\Phi_{i} \times \tau_{i}+\Psi_{i} \times \tau_{j}+\Sigma_{i} \times \lambda_{i}^{M}-\Omega_{i}=0
$$

where $\Phi_{i}, \Psi_{i}, \Sigma_{i}$ and $\Omega_{i}$ are positive bundles of parameters. Thus, the tax reaction function of a country $i$ boils down to:

with

$$
\tau_{i}=\frac{\Psi_{i}}{\Phi_{i}} \times \tau_{j}+\frac{\Sigma_{i}}{\Phi_{i}} \lambda_{i}^{M}-\frac{\Omega_{i}}{\Phi_{i}}
$$

$$
\begin{aligned}
\frac{\Psi_{i}}{\Phi_{i}} & =\frac{2(K+1)-\sigma_{i}(2 K+1)}{4(K+1)-\sigma_{i}(2 K+1)} \\
\frac{\Sigma_{i}}{\Phi_{i}} & =\frac{1}{\epsilon} \frac{2 K+2-\sigma_{i}}{4(K+1)-\sigma_{i}(2 K+1)} \\
\frac{\Omega_{i}}{\Phi_{i}} & =\frac{1}{\epsilon} \frac{\sigma_{i}(a-w+K c) / c}{4(K+1)-\sigma_{i}(2 K+1)}
\end{aligned}
$$

In the following, we will concentrate on the two first terms of the above expression, that is: the slope of the reaction function (first term) and the constant of the reaction function that depends on the structural attractiveness of the country (second term). ${ }^{4}$ By doing so, we can

is equal to the difference in gross return to capital evaluated at the core-periphery location equilibrium (see Ottaviano and Van Ypersele, 2005).

${ }^{4}$ The last component of equation (6) encapsulates the welfare loss from a marginal rise in taxation that depends 
analyse how the structural attractiveness of one country influences the fiscal policy of its government.

The slope of the reaction function is always positive and lower than 1 . We also observe that the government of the most populated country is less responsive to the tax policy of the other country since its tax base elasticity is lower than that of the less populated country. The second term of the reaction function indicates that everything else being equal and provided that trade costs are positive, the capital tax is increasing with the share of firms a country would attract thanks to market forces only. Indeed, the agglomeration of capital in a country reduces the tax base elasticity, and by doing so allows the government to raise its capital tax. This effect is also reflected in the expression of Nash taxes given by the intersection of the two best reply functions: $:^{5}$

$$
\tau_{i}^{*}=\frac{4 K \sigma_{i}+2-\sigma_{i}}{\epsilon(4 K+5)} \lambda_{i}^{M}+\Xi_{i}
$$

with

$$
\Xi_{i}=\frac{\left(2 K\left(1-\sigma_{i}\right)+2-\sigma_{i}\right)\left(2 K+1+\sigma_{i}\right)-2[(a-w+K c) / c]\left[K\left(1-\sigma_{i}\right)+\sigma_{i}^{2}(2 K+1)+1\right]}{2 \epsilon(4 K+5)(K+1)}
$$

Before confronting the above tax reaction function and the reduced form of Nash taxes to the data, it is of interest to point out that their properties are robust to numerous extensions. These results are qualitatively similar in a model where mobile firms produce horizontally differentiated goods (Ottaviano and van Ypersele, 2005), where capital owners live in a third country (Haufler and Wooton, 2010), or under alternative hypotheses regarding the behaviour of governments (for example, when they provide a public good, when they are Leviathan or when the government of the most populated country acts as a Stackelberg leader ${ }^{6}$ ).

\section{Empirical specification}

We consider that when deciding upon its tax policy, each national government $i$ adjusts its tax rate $\tau_{i t}$ to the average tax rate of the other countries $\bar{\tau}_{-i, t}$ instead of reacting to the tax rate of each country separately. This approach is standard in the literature, and allows us to solve the problem of the degrees of freedom that we would otherwise have. Given the linearity of the reaction function (6), one should thus test the following regression:

$$
\tau_{-i, t}=\alpha \bar{\tau}_{-i, t}+\beta R M P_{i t}+\delta^{\prime} \boldsymbol{X}_{i t}+\varepsilon_{i t}
$$

The $R M P_{i t}$ variable stands for the real market potential aimed at approximating the term $\lambda_{i}^{M}$ of the tax reaction function (see discussion in section 3.2), $\boldsymbol{X}_{\boldsymbol{i}}$ denotes a vector of control variables which will be discussed in section 3.2, and $\varepsilon_{i t}$ is an i.i.d. error term. The average tax rate of the other countries is defined as follows:

\footnotetext{
neither on the level of taxes nor on the location of firms. In what follows, we disregard this term since its analysis goes beyond the scope of this paper.

${ }^{5} \Xi_{i}$ is a bundle of parameters which captures the influence of the spatial distribution of capital ownership on corporate taxation. Analysing this relationship would go beyond the aim of the paper, so we disregard this term.

${ }^{6}$ We refer the reader to Gaigné and Riou (2007) for results under the assumption when governments are Leviathan. The results obtained when the government of the most populated country acts as a Stackelberg leader or when governments provide a public good are available from the author on request.
} 


$$
\bar{\tau}_{-i, t}=\sum_{j \neq i} \omega_{i j t} \tau_{j t}
$$

with $\omega_{i j t}$ the weights of a matrix normalized such that $\sum_{j \neq i} \omega_{i j t}=1$. The estimated regression written in matrix form is thus:

$$
\tau=\alpha W \tau+\beta R M P+\delta X+\varepsilon
$$

where $W$ denotes the weight matrix. The estimated coefficient $\hat{\alpha}$ gives the average responsiveness of country $i$ 's fiscal policy to all other countries of the sample, while the responsiveness of country $i$ 's corporate tax rate to country $j$ 's tax rate is given by $\hat{\alpha} \omega_{i j t}{ }^{7}$

This regression will be tested on a database that covers (up to) 26 OECD countries for the period from 1982 to 2006. ${ }^{8}$ These countries are: Australia, Austria, Canada, Czech Republic, Denmark, Germany, Hungary, Iceland, Spain, Finland, France, Great Britain, Greece, Italy, Ireland, Japan, the Netherlands, New Zealand, Norway, Poland, Portugal, Slovak Republic, Sweden, Switzerland, Turkey, and the United States of America. ${ }^{9}$ Data definitions, summary statistics, and sources are given in Table 1 of appendix A.2.

\subsection{Weighting schemes}

Unlike many existing empirical studies on international tax interactions, we use weight matrices inferred from the model. The model shows that a country responds more fiercely to its trading partner when the latter is more populated. Thus, we build a weight matrix based on the ratio of population in each competing country $j$ over population in country $i$ :

$$
\omega_{i j t}^{p o p}=\left(P O P_{j t} / P O P_{i t}\right) / \sum_{j \neq i}\left(P O P_{j t} / P O P_{i t}\right)
$$

with $P O P_{i t}$ the population in country $i .{ }^{10}$ Thus, the higher the population of country $j$ compared to country $i$, the higher the tax base elasticity in country $i$, and we expect its government to respond strongly to a tax cut in country $j$.

Although we would expect trade costs to attenuate interactions through their negative impact on the tax base elasticity, they cancel out in the slope of reaction function. However, with more sophisticated models we can show that the decline in trade costs strengthens tax interactions. This is true, for example, if we include infra-national trade costs, asymmetric trade costs across countries, or if we assume an endogenous labour supply so that the wage becomes dependent on the level of trade integration (see Exbrayat et al., 2012). Thus, we also

\footnotetext{
${ }^{7}$ Thus, even if we consider that each country adjusts its tax policy to the average tax rate of the other countries, it reacts more or less strongly to each one of them as far as we define non-uniform weight matrices.

${ }^{8}$ The starting point follows from the availability of corporate tax rate data (source: Loretz, 2008), while the endpoint is due to the lack of market potential data after 2006 (source: CEPII Market Potential Database). The final dataset is unbalanced since the data regarding some new EU member states is only available in the second part of the time period. As a robustness check (see section 4.2), we provide results using a smaller but balanced sample.

${ }^{9}$ We included all countries in the tax dataset by Loretz (2008), except Republic of Korea and Mexico for which there are many missing values for taxes or bilateral trade, as well as Belgium and Luxembourg for which the CEPII does not provide data on bilateral trade and market potential.

${ }^{10}$ Note that because of the row standardization, this is equivalent to using a weighting scheme based on the absolute population of each neighbouring country. However, this is not a problem. By expressing weights as a function of relative (rather than absolute) population, we can easily check that the derivative of $\omega_{i j t}^{\text {pop }}$ with respect to the relative population $\left(P O P_{j t} / P O P_{i t}\right)$ is positive.
} 
build a weight matrix based on a measure of bilateral trade integration $P H I_{i j t}$ defined by Head and Mayer (2004) (namely, the index of 'trade phi-ness'). Inferred from a new economic geography model (the Dixit-Stiglitz-Krugman model), this index is described by the square root of the ratio of trade flows between two countries over trade flows within each country (see appendix A.1). ${ }^{11}$ We believe that this would better capture the 'border effects' in explaining why countries are not as well integrated as one could expect if we focused exclusively on legal barriers to trade (McCallum, 1995; Wei, 1996). Moreover, this measure is bilateral and thus allows us to specify a more accurate weighting scheme than if we relied a standard trade openness variable. The resulting weight matrix is defined as follows:

$$
\omega_{i j t}^{p h i}=P H I_{i j t} / \sum_{j \neq i} P H I_{i j t}
$$

This approach complements the contribution by Davies and Voget (2011). They take into account the joint influence of trade integration and the market size of countries by testing whether each country responds more fiercely to the tax policy of neighbouring countries when the latter enjoy a higher market potential. By contrast, we aim at assessing the specific impact of trade liberalization on tax interactions.

We will compare the results of these two weighting matrices with other weighting schemes traditionally used in the literature, and that are aimed at approximating economic integration. The first matrix is based on FDI flows to capture the impact of capital mobility on tax interactions, and is defined as follows: ${ }^{12}$

$$
\omega_{i j t}^{f d i}=F D I_{j t} / \sum_{j \neq i} F D I_{j t}
$$

with $F D I_{j t}$ the sum of inward and outward FDI flows over the GDP in country $j$. A high and significant coefficient associated with this weighting matrix would mean that a government is more sensitive to the tax policy of other countries when those countries generate or host important FDI flows. The second weighting matrix approximates economic integration by the inverse of distance and uses the following weights:

$$
\omega_{i j}^{d i s t}=\left(1 / D I S T_{i j}\right) / \sum_{j \neq i}\left(1 / D I S T_{i j}\right)
$$

where $D I S T_{i j}$ stands for the geodesic distance between country $i$ and $j .^{13}$

Existing empirical studies also typically introduce a uniform matrix such that the corporate tax rate of each country is equally weighted. A well-known problem with this uniform matrix is that we cannot distinguish tax interactions caused by tax competition from a common period-specific shock (see Devereux et al., 2008). Hence, we do not use this uniform matrix, and we ensure that the same problem does not occur with the matrices we use by checking there is enough dispersion in the weights.

\footnotetext{
11 See Niepman and Felbermayr (2010) for another empirical study using the 'trade phi-ness' index to approximate trade liberalization.

${ }^{12}$ This measure is also used in empirical papers that estimate the impact of capital mobility on corporate tax rates (Dreher, 2006; Dreher et al., 2008).

${ }^{13}$ We use the CEPII database on bilateral distances. Geodesic distances are calculated following the great circle formula, which uses latitudes and longitudes of the most important cities/agglomerations (in terms of population).
} 


\subsection{Other variables}

We first comment on the measure of corporate taxation. We concentrate on ex ante measures that take into account the fiscal legislation (statutory tax rate, depreciation allowances, etc.) in order to evaluate the impact of taxes on the expected profits of a typical investment. ${ }^{14}$ While the statutory tax rate is the most direct measure of the tax rate, effective tax rates are theoretical measures combining information on both the tax rate and the tax base in order to estimate the effective fiscal burden on a typical investment. Specifically, the effective average tax rate (EATR) is aimed at evaluating the impact of taxes on location choices made by profitable firms, whereas the effective marginal tax rate (EMTR) matters for marginal investment choices made by firms conditional on their previous location choice (Devereux and Griffith, 1998). Since our theoretical framework considers an environment of lumpy investment, we choose as a benchmark case tax interactions in the setting of effective average tax rates, under the assumption that they are levied on machinery because this is a mobile and tradable good (unlike buildings). As robustness checks (see section 4.2), we then compare the results using effective marginal tax rates or statutory tax rates as dependent variables.

To approximate the attractiveness of a country resulting from market forces $\left(\lambda_{i}^{M}\right)$, we use a market potential variable. Indeed, empirical studies confirm that the domestic market size and the accessibility to foreign markets are the main determinants of firms' location choices (Benassy-Quéré et al., 2005; Devereux and Griffith, 1998; Head and Mayer, 2004b) whereas the fiscal policy has a marginal impact on the location of firms. Specifically, we rely on the real market potential variable provided by the CEPII, which has several advantages. ${ }^{15}$ First, it is estimated from a theory-grounded gravity equation, so that the endogeneity bias of such a variable is controlled for (see Head and Mayer, 2011). Secondly, it takes into account that the market potential in a country is not only increasing with demand coming from other countries but also decreasing with the average price in those countries, and thereby captures the market-crowding effect at work in the model. Thirdly, it is estimated using a dataset covering more than 150 countries, and thus allows us to indirectly take account of thirdcountry effects.

Finally, let us discuss the choice of control variables that compose the vector $\boldsymbol{X}_{i t}$. While these variables do not matter for the location of capital, they influence the government's tax policy through other channels. The size of the public sector is approximated by a variable for public consumption. Following Davies and Voget (2011), we limit the potential endogeneity bias of the public sector size in two ways: by expressing public consumption expenditures as the share over GDP and by taking the lagged value of this

\footnotetext{
${ }^{14}$ By contrast, ex post measures of corporate taxation are defined as a ratio of tax revenues over the tax base. Thus, they are backward-looking measures that cannot capture the impact of taxes on the behaviour of firms.

${ }^{15}$ For more information on the CEPII dataset, see http://www.cepii.fr/anglaisgraph/bdd/marketpotentials.htm. This dataset provides estimates of real market potential until 2003. In order to extend the data to 2006, we replicated what Head and Mayer (2011) call the "RV04" method. This consists in estimating a gravity-type regression à la Redding and Venables (2004), with a larger vector of trade impediments including not only distance and contiguity, but also common language, colonial links, and dummies for common membership of a regional trade agreement, a currency union or GATT/ WTO membership.
} 
variable $\left(\mathrm{PCONS}_{i, t-1}\right) .{ }^{16} \mathrm{We}$ expect this variable to have a positive impact on the corporate tax rate as it calls for more fiscal revenues to finance public goods. We also introduce the highest domestic income tax $\left(T I N C_{i t}\right)$, which we expect to exert a positive impact on the corporate tax rate. Indeed, the tax gap between personal and corporate income taxes could induce individuals to escape tax on their earnings by incorporating themselves. As a consequence, the corporate tax rate could act as a backstop for the income tax (Slemrod, 2004). Various socio-demographic variables are used in order to control for the effect of the structure of population on the fiscal policy: the share of young people $\left(Y O U_{i t}\right)$, the share of old people $\left(O L D_{i t}\right)$ and the share of people living in urban areas $\left(U R B_{i t}\right)$. We also control for the impact of the business cycle on the fiscal policy with GDP growth from year $t-1$ to year $t\left(G D P G R_{i t}\right)$. We expect economic growth to result in lower corporate taxation. Indeed, a positive productivity shock favours capital inflow. Thus, governments could lower their tax rates during economic upturns to have a balanced budget (Bretschger and Hettich, 2002). An EU membership dummy $E U_{i t}$ (equal to 1 if the country is a member of the EU and 0 otherwise) is also introduced to capture the specific behaviour of European countries. Finally, we follow Devereux et al. (2008) by allowing for the political persuasion of the governing party. We include a dummy variable indicating whether the party of government is to the right of centre $\left(R I G H T_{i t}\right)$, and we interact right-wing and left-wing dummies with the majority in parliament (MAJRIGHT $i t$ and MAJLEFT $T_{i t}$ variables) to account for the possibility that parties only have a decisive influence on tax rates if their majority is strong enough.

\subsection{Econometric issues}

We have to deal with three main problems to estimate the tax reaction function (8): endogeneity, serial correlation and heterogeneity.

Endogeneity. Strategic interactions in the setting of corporate tax rates imply that they are simultaneously determined. Hence, the average corporate tax rate of other countries $\bar{\tau}_{i t}$ is correlated with the residuals. To deal with this endogeneity, we have to find variables that are correlated with neighbours' endogenous average tax rate $\left(\bar{\tau}_{-i, t}\right)$, while not being correlated with $\varepsilon_{i t}$. As is common in the literature, we rely on the weighted average of neighbours' control variables as instruments. That is, in a first step we regress $W \tau$ on a subset of $W X$ and we use the predicted values $\widehat{W \tau}$ as instruments for $W \tau .{ }^{17}$ This identification strategy rests on the assumption that the neighbours' control variables are correlated with their average

\footnotetext{
${ }^{16}$ We thought of several instrumental variables to test for the potential endogeneity of public consumption expenditures. The literature usually relies on total population, economic openness or political variables as potential instruments for government size. These variables are not good instruments, however, as they are likely to exert an influence on corporate taxes. That is the reason why we treat this variable as exogenous and limit the endogeneity bias by taking its lagged value. As a further robustness check, we run regressions without the public consumption expenditures variable. This does not have any impact on our main results, which are either unchanged or even slightly more significant (available from the author on request).

${ }^{17}$ We limit the number of instruments because using too many instruments leads to inaccurate estimation of the optimal weight matrix, biased standard errors and, therefore, incorrect inference in over-identification tests (see Roodman, 2008).
} 
corporate tax, but are exogenous to the setting of the corporate tax in country $i$. We test the validity of the instruments by the Hansen test of over-identifying restrictions. The joint null hypothesis is that the instruments are uncorrelated with the error term. We also report the result of the Klebergen-Paap underidentification test to ensure that the equation is identified, i.e., that the excluded instruments are correlated with the endogenous regressors. The top income tax rate can also be endogenous since a government could decide simultaneously upon its corporate and income tax rates. We thus test for the endogeneity of this variable.

Serial correlation. There is a strong inertia in the evolution of corporate tax rates over time. We include a lagged dependent variable in order to deal with the resulting serial correlation bias. As is well known, this lagged dependent variable is correlated with the fixed effects, and thus treating it as exogenous may lead to biased estimates (Nickell, 1981). Since the Nickelbias is decreasing with $T$, we follow Devereux et al. (2007) by selecting the fixed effects estimator and instrumenting the lagged dependant variable by its second lag. ${ }^{18}$

Heterogeneity. We account for non-observable characteristics varying over time or space by introducing country fixed effects $v_{i}$ and a time trend $T r_{t}$. Indeed, adding time dummies would be formally equivalent to including the average tax of all countries. Being highly correlated with the weighted average of tax rates in other countries, such a variable makes it hard to disentangle the impact of time dummies from tax interactions. We therefore follow Klemm and Van Parys (2012) by using a linear time trend.

To summarize, we estimate the following spatial and temporal auto-regression:

$$
\tau_{i t}=\theta \tau_{i, t-1}+\alpha \bar{\tau}_{-i, t}+\beta R M P_{i t}+\delta^{\prime} X_{i t}+v_{i}+T r_{t}+\varepsilon_{i t}
$$

and we present the results of both the static model $(\theta=0)$ and the dynamic one $(\theta \neq 0)$.

\section{Results}

In a first step, we estimate the baseline regression on the sample of 26 OECD countries, using the effective average tax rate as the dependent variable. Next, we undertake various robustness checks.

\subsection{Baseline results}

The results of our baseline regression are described in Table 2. The two first columns report results without tax interactions, whereas columns [3] to [6] present the estimates when both a spatial and a time-lagged variable are introduced.

We first analyse the determinants of corporate taxes at the Nash equilibrium by

\footnotetext{
18 Alternative treatments of the Nickell bias are unfortunately unsatisfactory. The GMM estimator is not adapted to our sample. The set of instruments is too large, which overfits the endogenous variable and distorts the test of over-identifying restrictions (see Roodman, 2008; Bowsher, 2002). Restricting the set of instruments then yields another problem: the instability of results. More generally, as Beck and Katz (2004) argue, the motivating case for the development of these dynamic panel models was the case of very short panels with very small Ts. This alternative solution is therefore not adapted to our sample.
} 
describing the results of the static regression in column [1]. We present standard errors clustered by country, which are robust to serial correlation. Our findings are supportive of the model's prediction (see eq. (7)). We find a significantly positive effect of the real market potential on effective average tax rates. In terms of control variables, we treat the top income tax rate as exogenous because the Hausman test rejects the hypothesis of endogeneity of this variable. Consistent with Devereux et al. (2008), the coefficient of this variable is significantly positive. This suggests that the corporation tax is used as a "backstop" to income tax. Countries with a high share of young people tend to set lower effective average tax rates. In addition, the coefficient on EU membership is significantly negative. This suggests that European integration exerts a downward pressure on corporate taxation. However, those results might well be due to an omitted variable bias, because we do not control either for the influenced of the lagged dependant variable, nor for the impact of the other countries' tax rates. We address each of these issues in turn.

When choosing the current tax rate, national governments can be heavily restricted by the existing tax system. Ignoring this effect is likely to exert an upward bias on all coefficients estimated by the static regression. Therefore, in column [2] we add a lagged dependent variable and instrumental it by its second lag. The equation both passes the serial correlation test and the test of overidentifying restrictions. As expected, the lagged dependent variable is strongly significant, with a coefficient equal to 0.753. This confirms that there is a high persistence of effective average tax rates over time. Intuitively, controlling for this effect could challenge the significance of the other explanatory variables. Overesche and Rincke (2011) already demonstrated that, once the dependence of tax rates over time and tax competition is controlled for, country characteristics such as population size do not contribute much to explaining corporate tax rates in European countries. We may wonder whether this conclusion also holds regarding the impact of the market potential on corporate tax rates. The few existing empirical studies do not answer this question, since they do not include a lagged dependent variable (Charlot and Paty, 2007; Davies and Voget, 2011). Our findings reveal that the coefficient on real market potential variable becomes lower but remains significant at the 5\% level. Regarding the remaining control variables, the addition of the lagged dependent variable reduces the coefficient on EU membership and makes it insignificant. In contrast, a rise in public consumption relative to GDP significantly reduces the effective average tax rate. This could result from the fact that this variable includes both productive and non-productive expenditures, which we expect to exert an opposite impact on countries' relative attractiveness. As soon as non-productive expenditures become predominant, a rise in public expenditures can induce a capital outflow and lead governments to cut corporate taxation to limit this capital outflow. ${ }^{19}$ Note also that left-wing parties that benefit from a significant majority tend to set higher tax rates.

\footnotetext{
${ }^{19}$ This interpretation is also in line with the findings of Benassy-Quéré et al. (2007). Using a dataset of FDI flowing from the United States to 18 European countries in the period 1994-2002, their estimates reveal that funding a marginal increase in public capital through corporate taxation induces capital outflow, because public capital is not productive enough to compensate for the required increase in corporate taxation. Klemm and van Parys (2012) also point out that government consumption expenditures have a negative impact on FDI in Latin American, Caribbean and African countries for the period 1985-2004.
} 
In columns [3] to [6], we introduce the possibility of tax interactions by adding the weighted average of the effective average tax rates of the other countries. Each column corresponds to one of the four sets of weights described in section 3.1. Column [3] represents the relative population weights directly inferred from the theoretical framework. Columns [4] [5] and [6] rely on weights based on the phi-ness trade index, the inverse of distance and the ratio of FDI over GDP, respectively. For each column, the average tax rate is instrumented by the weighted average of a subset of control variables and we report the results of two tests regarding those instruments. The Hansen test of over-identifying restriction does not reject the validity of the instrument set. The regression also passes the Kleibergen-Paap underidentification test, indicating that the model is identified. In each column, most control variables remain significant. Importantly, the coefficient on real market potential is still positive and significant at the $1 \%$ or $5 \%$ level, with a coefficient varying between 0.16 and 0.25. This provides support for the theoretical prediction in eq. (6) that the structural attractiveness of a country allows its government to set a higher level of corporate taxation whatever the tax policy choices in the other countries.

The evidence regarding tax interactions is more equivocal. The results indicate that the slope of the reaction is significant and positive when the weighting matrix is based on the relative population. Specifically, we find a coefficient of 0.502 significant at $5 \%$ level. ${ }^{20}$ This finding is in line with results of Cassette and Paty (2008) and supports the theoretical prediction of the economic geography framework detailed in section $2 .^{21}$

In contrast, none of the three other weighting schemes yields significant tax interactions. This leads us to consider several explanations. The presence of outliers, in terms of distance (USA, Canada, Japan, Australia) or population (USA), could bias the estimates of the slope of reaction functions. Most of the existing studies that provide empirical evidence on tax interactions consider European countries (Cassette and Paty, 2008; Overesch and Rincke, 2011; Redoano, 2014), ${ }^{22}$ whereas we focus on OECD countries. The specificity of this sample could explain why the empirical evidence on strategic interactions is limited to the relative population weighting scheme. In addition, our sample is unbalanced. Therefore, the variation in the weights is partially caused by changes in the number of countries from year to year. Finally, governments might behave strategically with respect to statutory tax rates rather than effective average tax rates. In the following section, we provide several robustness checks in

\footnotetext{
${ }^{20}$ Recall that our theoretical model is a static one. We run a dynamic regression to check whether or not strategic tax interactions remain significant once we control for the inertia of corporate taxes over time. Our aim is not to quantify the long-run effect of tax competition. To do so, one has to test a regression allowing dynamic adjustment to shocks, period-specific and country-specific effects. We refer the readers to Overesch and Rincke (2011) for such an empirical study. They conclude that in the absence of tax competition, the mean statutory tax rate of Western European countries in 2006 would have been about 12.5 percentage points above its actual level.

${ }^{21}$ Most empirical studies on tax interactions rely on relative GDP rather than relative population weighting schemes in order to test whether tax interactions are increasing with the size of countries. They also find significant tax interactions using this weighting scheme. To some extent our result also points in the same direction, although using a weighting scheme which carries fewer suspicions of endogeneity.

${ }^{22}$ An exception is the contribution of Devereux et al. (2008), who consider 21 OECD countries over the period 1981-1999. Our results are not directly comparable as we have only the FDI weighting scheme in common and our sample is larger. Using this weighting scheme, they find significant interactions in the setting of statutory tax rates, but the test of over-identifying restrictions rejects the validity of the instrument set.
} 
order to address these issues.

\subsection{Robustness checks}

First, we estimate our baseline on two alternative samples. Then, we estimate the baseline regression using alternative tax measures. Finally, we further investigate the driving force behind tax interactions.

\section{(a) Alternative samples}

As a first step, Table 3 provides results on the largest balanced sample. This sample includes 18 countries over the period $1982-2006 .{ }^{23}$ One notices first that the $\mathrm{R}^{2}$ tends to be slightly higher for all specifications. Hence, the fact that the number of countries varies over time seems to limit the ability of the econometric model to explain the determinants of effective average tax rates. Moreover, this is not without consequences for the slope of the tax reaction function. Using a balanced sample, we provide some evidence of significant tax interactions in the case of both FDI and relative population weights. In the case of relative population weights, the coefficient is still significant at the $5 \%$ level, but there is some evidence of serial correlation. Importantly, when taxes of the other countries are weighted by their share of FDI over GDP (column [6]), the coefficient of tax interactions becomes significant at the $10 \%$ level with a value equal to 0.277 . Finally, we verify that whatever the weighting scheme, the empirical evidence regarding the positive influence of the real market potential on effective average tax rates is very robust, with a coefficient significant at the $1 \%$ level.

Next, we estimate the regressions on European countries exclusively. The aim is to figure out whether the existence of outliers in terms of distance could influence the empirical evidence regarding the pattern of tax interactions. To define European countries, we rely on the United Nations categorization of geographical regions of the world. We are left with a sample of 20 countries. ${ }^{24}$ Results are reported in Table 4. As one can see from columns [3] to [5], the coefficient on the slope of the tax reaction is significant at the $10 \%$ level when countries' tax rates are weighted by their relative population, their bilateral level of trade integration or the inverse of distance. The coefficient varies from 0.246 (with distance weights) to 0.488 (relative population weights). Those results are consistent with the existing empirical studies on tax competition in Europe (Cassette and Paty, 2008; Redoano, 2014). In line with Cassette and Paty (2008), who estimate tax interactions in the European Union over the period 1995-2005 through a dynamic model, we do not find support for the existence of tax interactions with respect to countries with a high ratio of FDI over GDP. ${ }^{25}$

\footnotetext{
${ }^{23}$ These countries are Australia, Austria, Canada, Switzerland, Germany, Spain, Finland, France, Great Britain, Greece, Ireland, Italy, Japan, Netherlands, Norway, Portugal, Sweden and the United States.

${ }^{24}$ France, Switzerland, Portugal, Ireland, Iceland, Netherlands, Norway, Austria, Italy, Greece, Great Britain, Germany, Finland, France, Spain, Poland, Denmark, Hungary, Slovak republic, and Sweden.

${ }^{25}$ Once they consider the possibility that Western and Eastern states would respond differently depending on the group of countries they interact with, Cassette and Paty (2008) show that tax interactions using the FDI
} 
Unlike existing studies on tax competition in Europe, we also provide evidence that bilateral trade integration gives rise to significant interactions in the setting of effective average tax rates. In the meantime, the real market potential is again significant at the $1 \%$ level whatever the weighting scheme, with a coefficient slightly higher than for the two other samples. Interestingly, this means that trade integration in Europe exerts two opposite pressures on the effective average tax rate. On the one hand, the decline in trade costs strengthens tax interactions and contributes to the fall in corporate taxation. On the other hand, everything else being equal, it raises the real market potential and allows governments to set a higher tax rate.

Finally, the political orientation of the government significantly influences tax choices in European countries. Higher effective average tax rates are associated with both right-wing parties and left-wing parties which have a significant majority. ${ }^{26}$

\section{b) Alternative tax measures}

We now provide the results of the baseline regression by using alternative measures of corporate taxation. Recall that the effective average tax rate is the relevant indicator of the tax burden on profitable projects that generate economic rents, while the effective marginal tax rate approximates the tax burden attributable to a marginal non-profitable investment. Moreover, the NEG literature suggests that governments compete for discrete investments. Thus, we can expect the above theoretical predictions to be more relevant for investigating the determinants of effective average tax rates than those of effective marginal tax rates. We also test for tax interactions in the setting of the statutory tax rate because: (i) it could be easier for governments to manipulate statutory tax rates than to change the definition of the tax base, (ii) the comparison of statutory tax rates between countries is easier for firms than the comparison of effective tax rates, and (iii) governments could compete over statutory tax rates to attract profits made by multinationals which adopt tax optimisation behaviour (Devereux et al., 2008).

As one can see from Table 5, the regression regarding effective marginal tax rates performs poorly. In line with the results of Devereux et al. (2008) or Overesch and Rincke (2011), the $R^{2}$ is significantly lower and none of the weighting schemes suggests the existence of tax interactions. In addition, the results reveal that the real market potential almost never significantly influences the effective tax rate level. ${ }^{27}$ This is exactly what we expected given that the effective marginal tax rate is not a relevant measure when it comes to evaluating the impact of fiscal policy on firms' location choices. ${ }^{28}$

\footnotetext{
weighting scheme become significant.

${ }^{26}$ Devereux et al. (2008) find similar results for their sample of 21 OECD countries. While at first sight this evidence seems to conflict, it might be explained by the possibility of dual competition on tax rates and public inputs. Right-wing parties might be willing to raise corporate taxes if fiscal revenues are used to finance public inputs that are attractive for firms, whereas left-wing parties would be prone to set a higher corporate tax in order to finance social expenditures.

${ }^{27}$ The only exception appears in column [3]. When we use relative population weights to build the strategic tax variable, the real market potential variable is marginally significant.

${ }^{28}$ Another explanation we cannot exclude is that the construction of effective marginal tax rates relies on some assumptions that might not reflect the influence of the economic environment on investment decisions.
} 
As a robustness check we also test interactions in the setting of statutory tax rates. The results in Table 6 reveal the existence of significant tax interactions for both relative population and trade integration weighting schemes. Thus, bilateral trade integration seems to contribute to the decline in statutory tax rates by giving rise to strategic behaviour on the part of governments. We might object that this provides empirical evidence for competition to attract mobile profits, rather than mobile firms. Indeed, what matters the most for tax optimization strategies is the relative level of statutory tax rates, rather than the definition of the tax base. Observe, however, that the coefficient of the real market potential is even more significant and on average more than two times higher than its impact on the effective average tax rate. Given that the location of profits should depend on profit-shifting incentives rather than on the market potential, we can surmise that competition over the statutory tax rate is not exclusively aimed at attracting profits but also at attracting profitable firms. In fact, our results might suggest that governments prefer to reduce their statutory tax rate rather than to narrow their tax base (through effective average tax rates) in order to improve their attractiveness.

\section{c) Is it all about tax competition for mobile firms?}

So far we have considered the possibility that governments compete for firms, for marginal investment decisions, or for mobile profits. Besides those motives, we can think of other reasons for the existence of international interdependencies in the setting of corporate taxes. Tax interactions could also result from yardstick competition (Besley and Case, 1995; Bordignon et al., 2003): in such a case, strategic interactions are induced by the behaviour of citizens, not by the mobility of capital. The intuition is that policy-makers in one country could adjust their policy in response to neighbouring countries because citizens compare domestic and foreign policies to make their voting decisions. The relevance of this hypothesis can be tested by introducing a dummy for the years of election, or/and by observing the interaction of this dummy with the strategic tax variable. Doing so, Cassette and Paty (2008) and Redoano (2014) do not find support for the existence of yardstick competition. This is not surprising, as the level of corporate tax may not be the policy decision that citizens care about the most.

Becker and Davies (2015) suggest an alternative explanation for the empirical evidence of tax interactions. They build a model in which countries have incomplete information regarding the true state of nature. This means that, regarding the corporate tax policy for example, governments do not observe firms' responsiveness to changes in corporate taxation (especially for firms located in foreign countries). Therefore, governments refine their beliefs by observing the policies set elsewhere. As a consequence, they set policies as if they react to each other. Importantly, those 'fake' tax interactions will depend on the determinants of the network formation. Geographical proximity, capital mobility, trade integration or the relative population size of the other countries are all potential criteria that one country might retain when deciding upon the set of countries from which it will learn. Therefore, we can hardly preclude the possibility that such a mechanism of social learning might also drive the results. However, this alternative source of tax interdependencies is again more relevant for policies that are easy to observe and compare across countries. This is not 
the case for the effective average tax rate as this depends on a combination of statutory tax rates and the definition of the corporate tax base. By considering the effective average tax rate as a dependent variable, we therefore alleviate the possibility that yardstick competition or social learning could drive our results.

Moreover, recall that tax competition for firms occurs if and only if firms are mobile and responsive to tax differentials. Following Devereux et al. (2008), we further investigate the importance of capital mobility for tax interactions by allowing the coefficient $\alpha$ to vary with the degree of capital mobility of countries. We approximate capital mobility by the Index of Capital Mobility Constraints (ICMC) from the Economic Freedom of the World database. This index combines information about foreign investment restrictions (taken from the Global Competitiveness Report) and international capital controls (taken from the IMF) into a 10point scale, where increasing numbers indicate higher capital mobility. We cannot allow the coefficient of tax interaction to vary by country, due to lack of degrees of freedom. Therefore we simply divide observations between two groups of countries: those where the average ICMC index is above, respectively below, the median level of the ICMC (6.22). This generates a dummy variable $O_{i}$ that takes the value 0 if country $i$ belongs to the group of relatively 'closed' economies (ICMC $<6,22$ ) and 1 if it belongs to the group of relatively 'open' economies (ICMC $\geq 6,22)$. ${ }^{29}$ This allows us to construct the average tax rate of the other 'open' countries $\left(\bar{\tau}_{-i, t}^{O}\right)$ and 'closed' countries $\left(\bar{\tau}_{-i, t}^{C}\right)$ as follows:

$$
\bar{\tau}_{-i, t}^{O}=\sum_{j \neq i} \omega_{i j t} O_{j} \tau_{j t} \text { and } \bar{\tau}_{-i, t}^{C}=\sum_{j \neq i} \omega_{i j t}\left(1-O_{j}\right) \tau_{j t}
$$

Next, we estimate this extended regression:

$$
\begin{aligned}
\tau_{-i, t} & =\theta \tau_{i, t-1}+\alpha_{1} O_{i} \bar{\tau}_{-i, t}^{O}+\alpha_{2} O_{i} \bar{\tau}_{-i, t}^{C}+\alpha_{3}\left(1-O_{i}\right) \bar{\tau}_{-i, t}^{O} \\
& +\alpha_{4}\left(1-O_{i}\right) \bar{\tau}_{-i, t}^{C}+\beta R M P_{i t}+\delta^{\prime} X_{i t}+v_{i}+T r_{t}+\varepsilon_{i t}
\end{aligned}
$$

If governments compete on taxes to attract firms, we would expect tax interactions to be significant only between open countries $\left(\alpha_{1}>0\right)$.

We report results for the unbalanced sample in Table 7. Our findings indeed reveal significant tax interactions between open economies in the case of the relative population weights (column [3]) and trade integration weights (column [4]). In addition, countries that are relatively closed to flows of capital interact significantly with those that are open to capital flows when taxes are weighted by the relative population. ${ }^{30}$ Given the way we build the dummy variable $O_{i}$, this result might rather suggest that the 'less open' economies interact in taxes only with respect to those countries that are 'more open' to capital flows because the tax base elasticity is higher with respect to those countries. Overall, we believe these results

\footnotetext{
${ }^{29}$ While the index of capital mobility constraint varies over time, the set of countries belonging to the 'open economies' and 'closed economies' groups is fairly stable.

${ }^{30} \mathrm{We}$ also estimated this extended regression for the balanced sample and the Europe sample (results available from the author upon request). Whatever the weighting scheme, the coefficients $\alpha_{2}$ and $\alpha_{4}$ are never significant. In other words, whatever the degree of capital mobility in one country, this country does not interact in the setting of corporate taxes with respect to countries where restrictions to capital mobility are strong. In contrast, coefficients $\alpha_{1}$ and $\alpha_{3}$ remain significantly positive when the relative population weight is employed for the balanced sample. Regarding the subsample of European countries, tax interactions are positive and significant exclusively between open economies $\left(\alpha_{1}>0\right)$ when weights are defined by the inverse of distance.
} 
provide further evidence that tax competition for firms is at least one mechanism which contributes to explaining the interdependencies in corporate taxes at the international level.

\section{d) Further robustness checks}

Finally, we undertook two additional robustness checks regarding the way we account for the influence of the time dimension on corporate taxes. ${ }^{31}$ To account for non-observable characteristics varying over time, we run regressions with a dummy for each decade in addition to the time trend. Results in Table 2 and Table 7 are robust to such an extension. In addition, we considered the possibility that governments react to the lagged - rather than contemporary - average tax rate of other countries (for a discussion about theories of tax competition in a dynamic framework, see Keen and Konrad, 2013). Most of the coefficients of tax interactions are not significant anymore, thus providing little suggestion that tax decisions could be made sequentially over a time period longer than one year.

\section{Conclusion}

This paper evaluates the empirical relevance of the tax competition literature based on the new economic geography literature, by estimating reaction functions over different measures of corporate taxation on a panel of 26 OECD countries between 1982 and 2006.

We provide striking support for the two main predictions inferred from a simple economic geography framework. First, national governments seem to adjust their effective average tax rate towards the level chosen in countries with higher populations, because the tax base elasticity is higher with respect to these countries. Moreover, given the tax policy in the other countries, governments tend to set higher corporate tax rate when their own country enjoys a high real market potential. This suggests that agglomeration economies create rents that the government can tax away without inducing a large capital outflow. Importantly, those results are very robust.

Unlike most of the existing empirical studies that examine the importance of capital mobility for tax competition, we also provide empirical evidence regarding the role played by trade liberalization. Specifically, we investigate the impact of trade liberalization on both the slope and the constant of the tax reaction function. Everything else being equal, trade integration exerts a positive influence on corporate taxes by improving the real market potential. The empirical evidence regarding its influence on the slope of the reaction function is clear-cut. Bilateral trade liberalization gives rise to significant strategic interactions in the setting of statutory tax rates, whereas the empirical evidence regarding its impact on effective average tax rates is limited to the subsample of European countries. In those cases, the decline in trade costs thus exerts an ambiguous impact on corporate taxes. It contributes to the downward adjustment in corporate taxes by strengthening tax interactions, but it might also raise taxes by improving the market potential of countries. This finding provides some support for the prediction, brought out in the literature on tax competition based on the economic geography framework, of a non-monotonous relationship between corporate taxes and trade costs.

\footnotetext{
${ }^{31}$ To save space we do not report those results, but they are available from the author upon request.
} 
To conclude, we aimed at providing some evidence for the existence of competition for firms, rather than claiming that this is the only explanation at work. Of course we may consider the possibility that other theories, such as tax competition for profits, yardstick competition or social learning could partially drive our results. Unlike these alternative theories, which provide predictions regarding the slope of the reaction function, the theory of tax competition for firms in a lumpy world provides determinants for both the slope and the constant of corporate tax rates. Importantly, our empirical results suggests that this theory contributes to explaining both the downward trend in the evolution of corporate taxes and the persistence of higher taxes in countries that enjoy a high market potential. ${ }^{32}$

\section{References}

Andersson F. and Forslid R. (2003). Tax competition and economic geography. Journal of Public Economic Theory 5 (2), 279-303.

Baldwin R.E. and Krugman P. (2004). Agglomeration, integration and tax harmonisation. European Economic Review 48, 1-23.

Beck N. and J. Katz (2004). Time-Series-Cross-Section Issues: Dynamics.

Becker, J. and R. B. Davies (2015). Learning and International Policy Diffusion - The Case of Corporate Tax Policy. UCD Centre for Economic Research Working Paper Series; WP2015/19

Bénassy-Quéré A., L. Fontagné and A. Lahrèche-Révil (2005). How does FDI react to corporate taxation? International Tax and Public Finance 12(5), 583-603.

Bénassy-Quéré A., Gobalraja N. and A. Trannoy (2007). Tax and public input competition. Economic Policy, 22(50), 385-430.

Besley T. and A. Case (1995). Incumbent Behavior: Vote Seeking, Tax Setting and Yardstick Competition. American Economic Review 85, 25-45.

Bordignon, M., Cerniglia, F., Revelli, F. (2003). In search of yardstick competition: a spatial analysis of Italian municipality property tax setting. Journal of Urban Economics 54, 199217

Bowsher, C. G. (2002). On testing overidentifying restrictions in dynamic panel data models. Economics Letters, 77, 211-220.

Bretschger L. and F. Hettich (2002). Globalisation, Capital Mobility and Tax Competition: Theory and Evidence for OECD countries. European Journal of Political Economy 18, 695716.

Bucovetsky S. (1991). Asymmetric tax competition. Journal of Urban Economics 30, 67-181. Cassette A. and S. Paty (2008). Tax competition among Eastern and Western European countries: With whom do countries compete? Economic Systems 32, 307-325.

Charlot S. and S. Paty (2007). Market access effect and local tax setting: evidence from french panel data. Journal of Economic Geography 7, 247-263.

Davies, R. B. and J. Voget (2011). Tax competition in an expanding European Union. GEE

\footnotetext{
${ }^{32}$ Exbrayat and Geys (2014) also provide empirical evidence for the positive impact of the real market potential on corporate taxes, by estimating the determinants of international differentials in corporate tax rates.
} 
Papers, 0033.

Devereux M.P and R. Griffith (1998). Taxes and the location of production: evidence from a panel of US multinationals. Journal of Public Economics 68, 335-367.

Devereux M.P., Lockwood B. and M. Redoano (2007). Horizontal and vertical indirect tax competition: Theory and some evidence from the USA. Journal of Public Economics 91, 451-479.

Devereux M.P., Lockwood B. and M. Redoano (2008). Do countries compete over corporate tax rates? Journal of Public Economics, 92, 1210-1235.

De Mooij R.A. and S. Ederveen (2003). Taxation and Foreign Direct Investment: A Synthesis of Empirical Research. International Tax and Public Finance 10, 673-693.

Dreher A. (2006). The influence of globalization on taxes and social policy: an empirical analysis for OECD countries. European Journal of Policital Economy 22 (1), 179-201.

Dreher A., Sturm J-E and H. W. Ursprung (2008). The Impact of Globalization on the Composition of Government Expenditures. Evidence from Panel Data. Public Choice, 134(34), 263-292.

Exbrayat N. and B. Geys, (2014), Trade Integration and Business Tax Differentials: Evidence from OECD Countries, International Tax and Public Finance, 21(2), 298-323.

Exbrayat N., Gaigné C. and S. Riou (2012) "The effects of labor unions on international capital tax competition", Canadian Journal of Economics, 45(4), 1480-1503.

Gaigné C. and S. Riou (2007). Globalization, asymmetric tax competition and fiscal equalization. Journal of Public Economic Theory 9(5), 757-925.

Haufler A. and I. Wooton (2010). Competition for firms in an oligopolistic industry: The impact of economic integration. Journal of International Economics 80 (2), 239-248.

Head, K. and T. Mayer (2004a), 'The empirics of agglomeration and trade', in V. Henderson and J. F. Thisse (eds.), Handbook of Regional and Urban Economics, Vol. 4 (Amsterdam: Elsevier), 2609-69.

Head K. and Mayer T. (2004b). Market Potential and the Location of Japanese Firms in the European Union. Review of Economics and Statistics 86(4) : 959-972.

Head, K. and Mayer T. (2011). Gravity, Market Potential and Development, Journal of Economic Geography, 11(2): 281-294.

Hühnerbein O. and T. Seidel (2010). Intra-regional tax competition and economic geography. The World Economy 33: 1042-1051.

Keen, M. and Konrad, K. A. (2013). The theory of international tax competition and coordination. In: Auerbach, A. J. , Chetty, R. , Feldstein, M. and Saez, M. (eds.), Handbook of Public Economics, Volume 5. Amsterdam \& Oxford, Elsevier, pp. 257-328.

Klemm A. and S. Van Parys (2012). Empirical Evidence on the Effects of Tax Incentives. International Tax and Public Finance 19(3), 393-423.

Loretz S. (2008). Corporate taxation in the OECD in a wider context. Oxford Review of Economic Policy 24(4), 639-660.

Ludema R. and I. Wooton (2000). Economic geography and the fiscal effects of regional integration. Journal of International Economics 52, 331-357.

Mc Callum J. (1995). National Borders Matters: Canada-US Regional Trade Patterns. 
American Economic Review 85(3), 615-623.

Nickell, S. J. (1981). Biases in dynamic models with fixed effects. Econometrica, 49(6), 1417-1426.

Niepman F. and G. Felbermayr (2010). Globalization and the spatial concentration of production. The World Economy, 33(5), 680-709.

Ottaviano G. and T. Van Ypersele (2005). Market access and tax competition. Journal of International Economics 67, 25-46.

Overesch M. and J. Rincke (2011). What drives corporate taxes down? A reassessment of globalization, tax competition and dynamic adjustment to schocks. Scandinavian Journal of Economics 113(3) 579-602.

Redoano, M. (2014). Tax competition among European countries. Does the EU matter? European Journal of Political Economy, 34, 353-371

Roodman, D. (2008). A Note on the Theme of Too Many Instruments. Oxford Bulletin of Economics and Statistics, 71, 135-158.

Slemrod J. (2004). Are corporate tax rates, or countries, converging? Journal of Public Economics 88, 1169- 1186

Wei S-J.. (1996). Intra-National Versus International Trade : How Stubborn Are Nations in Global Integration? National Bureau of Economic Research Working Paper $n^{\circ} 5531$.

Wilson J. D. (1991). Tax competition with interregional differences in factor endowments. Regional Science and Urban Economics 21, 423-452.

Zodrow G. and Mieszkowski P. (1986). Pigou, Tiebout, property taxation and the underprovision of local public goods. Journal of Urban Economics 19, 356-370.

\section{A. Appendix}

\section{A.1. Bilateral trade liberalization index}

In order to approximate the level of bilateral trade integration, we build on the multi-country version of the Dixit-Stiglitz-Krugman model, where firms operate in a market with monopolistic competition and barriers to trade (Head and Mayer, 2004a). Under the hypotheses of no trade costs at the subnational scale and symmetric trade costs at the international scale, this model yields the following index of trade phi-ness:

$$
P H I_{i j}=\sqrt{\left(X_{i j} X_{j i}\right) /\left(X_{i i} X_{j j}\right)}
$$

with $X_{i j}$ the total value of exports from country $i$ to country $j$, and $X_{i i}$ the total value of trade flows inside country $i$.

We use the Trade and Production database of the CEPII, which collects bilateral trade flows at the ISIC rev2 3-digit industry level (26 industrial sectors) from 1980 to 2006. By summing trade flows across sectors, we obtain the relative index of bilateral trade integration PHI $I_{i j t}$. 


\section{A.2. Data sources and summary statistics}

\section{Definitions and data sources}

$E A T R_{i t}, E M T R_{i t}$ and $S T A T T A X_{i t}$ : effective average tax rate, effective marginal tax rate and statutory tax rate (Loretz, 2008).

$T I N C_{i t}$ : top marginal income tax rate (World Tax Database and OECD tax database).

PHI $I_{i j t}$ : trade phi-ness index (our calculations, sources: Trade and Production database).

$F D I_{i t}$ : sum of inward and outward FDI flows over GDP (in current \$) (World Development Indicators).

PCONS $i t$ : general government final consumption expenditures in percentage of GDP (World Development Indicators).

$R M P_{i t}$ : real market potential $\left(\times 10^{11}\right)$ (CEPII market potential database, and own calculations).

$U R B_{i t}$ : proportion of population living in urban areas (World Development Indicators).

$O L D_{i t}$ : proportion of population more than 65 years old (World Development Indicators).

$Y O U_{i t}$ : proportion of population less than 14 years old (World Development Indicators).

$G_{D P G R}$ it : GDP growth from year $t-1$ to year $t$ (World Development Indicators).

RIGHT $_{i t}$ : Coded 1 if executive right-wing, 0 if center or left-wing (Database of Political Institutions 2012)

$M A J_{i t}$ : Fraction of seats held by government in legislature (Database of Political Institutions 2012) 
Table 1: Summary statistics (baseline sample)

\begin{tabular}{|c|c|c|c|c|c|}
\hline Variable & observations & mean & std. Dev. & $\min$ & $\max$ \\
\hline$\overline{S T A T T A X_{i t}}$ & 631 & 0.366 & 0.114 & 0.1 & 0.65 \\
\hline$E M T R_{i t}$ & 607 & 0.226 & 0.116 & -0.844 & 0.4867 \\
\hline$E A T R_{i t}$ & 607 & 0.275 & 0.086 & 0.05 & 0.488 \\
\hline$R M P_{i t}$ & 652 & 0.010 & 0.016 & 0.00008 & 0.105 \\
\hline $\operatorname{TINC}_{i t}$ & 640 & 0.429 & 0.145 & 0.07 & 0.844 \\
\hline$Y O U_{i t}$ & 702 & 20.187 & 4.252 & 13.574 & 39.822 \\
\hline$O L D_{i t}$ & 702 & 13.464 & 2.833 & 4.377 & 21.021 \\
\hline$U R B_{i t}$ & 702 & 72.4 & 10.627 & 43.287 & 93.2718 \\
\hline $\operatorname{PCONS}_{i t}$ & 680 & 19.211 & 4.158 & 7.516 & 29.594 \\
\hline$G D P G R_{i t}$ & 678 & 2.724 & 2.577 & -14.574 & 11.495 \\
\hline$R I G H T_{i t}$ & 679 & 0.573 & 0.130 & 0.255 & 1 \\
\hline$M A J_{i t}$ & 692 & 0.419 & 0.494 & 0 & 1 \\
\hline
\end{tabular}




\section{A.3. Results}

Table 2: Baseline regression on effective average tax rates (unbalanced sample)

\begin{tabular}{|c|c|c|c|c|c|c|}
\hline & \multicolumn{2}{|c|}{$\begin{array}{l}\text { Model without tax } \\
\text { interactions }\end{array}$} & \multicolumn{4}{|c|}{ Model with tax interactions } \\
\hline & {$[1]$} & {$[2]$} & $\begin{array}{c}{[3]} \\
\text { Relative } \\
\text { population } \\
\text { matrix }\end{array}$ & $\begin{array}{c}4] \\
\text { Trade } \\
\text { phiness } \\
\text { matrix }\end{array}$ & $\begin{array}{c}5] \\
\text { Distance } \\
\text { matrix }\end{array}$ & $\begin{array}{c}6] \\
\text { FDI matrix }\end{array}$ \\
\hline Lagged tax & & $\begin{array}{c}0.735 * * * \\
(0.035)\end{array}$ & $\begin{array}{c}0.753 * * * \\
(0.035)\end{array}$ & $\begin{array}{c}0.707^{* * *} \\
(0.045)\end{array}$ & $\begin{array}{c}0.745^{* * *} \\
(0.039)\end{array}$ & $\begin{array}{c}0.739 * * * \\
(0.036)\end{array}$ \\
\hline $\begin{array}{l}\text { Average tax of other } \\
\text { countries }\end{array}$ & & & $\begin{array}{l}0.502 * * \\
(0.251)\end{array}$ & $\begin{array}{c}0.441 \\
(0.299)\end{array}$ & $\begin{array}{c}0.102 \\
(0.196)\end{array}$ & $\begin{array}{c}0.106 \\
(0.269)\end{array}$ \\
\hline Real market potential & $\begin{array}{l}0.561 * * \\
(0.284)\end{array}$ & $\begin{array}{r}0.171 * * \\
(0.066)\end{array}$ & $\begin{array}{c}0.249 * * * \\
(0.075)\end{array}$ & $\begin{array}{l}0.248 * * \\
(0.116)\end{array}$ & $\begin{array}{l}0.159 * * \\
(0.069)\end{array}$ & $\begin{array}{l}0.179 * * \\
(0.073)\end{array}$ \\
\hline Top income tax rate & $\begin{array}{l}0.147^{* *} \\
(0.060)\end{array}$ & $\begin{array}{l}0.057^{* *} \\
(0.023)\end{array}$ & $\begin{array}{l}0.044 * * \\
(0.021)\end{array}$ & $\begin{array}{c}0.035 \\
(0.030)\end{array}$ & $\begin{array}{l}0.056 * * \\
(0.024)\end{array}$ & $\begin{array}{l}0.055^{* *} \\
(0.024)\end{array}$ \\
\hline Proportion old & $\begin{array}{l}-0.004 \\
(0.005)\end{array}$ & $\begin{array}{c}-0.003 * * \\
(0.002)\end{array}$ & $\begin{array}{c}-0.004 * * * \\
(0.001)\end{array}$ & $\begin{array}{c}-0.004 * * \\
(0.002)\end{array}$ & $\begin{array}{c}-0.003 * * \\
(0.002)\end{array}$ & $\begin{array}{c}-0.003 * * \\
(0.002)\end{array}$ \\
\hline Proportion young & $\begin{array}{c}-0.011 * * \\
(0.005)\end{array}$ & $\begin{array}{c}-0.004 * * * \\
(0.001)\end{array}$ & $\begin{array}{c}-0.004 * * * \\
(0.001)\end{array}$ & $\begin{array}{c}-0.003 * * * \\
(0.001)\end{array}$ & $\begin{array}{c}-0.003 * * * \\
(0.001)\end{array}$ & $\begin{array}{c}-0.003 * * * \\
(0.001)\end{array}$ \\
\hline Proportion urban & $\begin{array}{c}0.000 \\
(0.003)\end{array}$ & $\begin{array}{c}0.001 \\
(0.001)\end{array}$ & $\begin{array}{c}0.001 \\
(0.001)\end{array}$ & $\begin{array}{c}0.001 \\
(0.001)\end{array}$ & $\begin{array}{c}0.001 \\
(0.001)\end{array}$ & $\begin{array}{c}0.001 \\
(0.001)\end{array}$ \\
\hline Public consumption/GDP & $\begin{array}{l}-0.005 \\
(0.003)\end{array}$ & $\begin{array}{l}-0.002 * * \\
(0.001)\end{array}$ & $\begin{array}{l}-0.002 * * \\
(0.001)\end{array}$ & $\begin{array}{l}-0.002 \\
(0.001)\end{array}$ & $\begin{array}{c}-0.002 * * \\
(0.001)\end{array}$ & $\begin{array}{c}-0.002 * * \\
(0.001)\end{array}$ \\
\hline GDR growth & $\begin{array}{l}-0.000 \\
(0.001)\end{array}$ & $\begin{array}{l}-0.001 \\
(0.001)\end{array}$ & $\begin{array}{l}-0.001 \\
(0.001)\end{array}$ & $\begin{array}{l}-0.001 \\
(0.001)\end{array}$ & $\begin{array}{l}-0.001 \\
(0.001)\end{array}$ & $\begin{array}{c}-0.001 \\
(0.001)\end{array}$ \\
\hline Right & $\begin{array}{c}0.021 \\
(0.027)\end{array}$ & $\begin{array}{c}0.003 \\
(0.010)\end{array}$ & $\begin{array}{c}0.001 \\
(0.010)\end{array}$ & $\begin{array}{c}0.004 \\
(0.010)\end{array}$ & $\begin{array}{c}0.003 \\
(0.010)\end{array}$ & $\begin{array}{c}0.003 \\
(0.010)\end{array}$ \\
\hline Right*Majority & $\begin{array}{l}-0.001 \\
(0.043)\end{array}$ & $\begin{array}{c}0.019 \\
(0.014)\end{array}$ & $\begin{array}{c}0.021 \\
(0.014)\end{array}$ & $\begin{array}{c}0.015 \\
(0.015)\end{array}$ & $\begin{array}{c}0.019 \\
(0.015)\end{array}$ & $\begin{array}{c}0.019 \\
(0.014)\end{array}$ \\
\hline Left*Majority & $\begin{array}{c}0.020 \\
(0.031)\end{array}$ & $\begin{array}{c}0.022 * * \\
(0.011)\end{array}$ & $\begin{array}{l}0.020^{*} \\
(0.011)\end{array}$ & $\begin{array}{l}0.018^{*} \\
(0.010)\end{array}$ & $\begin{array}{l}0.021^{*} \\
(0.011)\end{array}$ & $\begin{array}{c}0.022 * * \\
(0.011)\end{array}$ \\
\hline EU & $\begin{array}{c}-0.059 * * * \\
(0.017)\end{array}$ & $\begin{array}{l}-0.004 \\
(0.007)\end{array}$ & $\begin{array}{l}-0.004 \\
(0.006)\end{array}$ & $\begin{array}{c}0.001 \\
(0.007)\end{array}$ & $\begin{array}{l}-0.002 \\
(0.008)\end{array}$ & $\begin{array}{c}-0.004 \\
(0.007)\end{array}$ \\
\hline Trend & $\begin{array}{c}-0.004 * * * \\
(0.001)\end{array}$ & $\begin{array}{c}-0.001 * * * \\
(0.000)\end{array}$ & $\begin{array}{c}0.001 \\
(0.001)\end{array}$ & $\begin{array}{c}0.001 \\
(0.001)\end{array}$ & $\begin{array}{l}-0.001 \\
(0.001)\end{array}$ & $\begin{array}{l}-0.000 \\
(0.001)\end{array}$ \\
\hline Country dummies & yes & yes & yes & yes & yes & yes \\
\hline Hansen test (p-val) & & 0.363 & 0.434 & 0.635 & 0.426 & 0.946 \\
\hline K-P-under (p-val) & & 0.000 & 0.000 & 0.040 & 0.096 & 0.000 \\
\hline Observations & 577 & 529 & 529 & 517 & 529 & 529 \\
\hline R-squared & 0.50 & 0.81 & 0.81 & 0.79 & 0.81 & 0.81 \\
\hline $\begin{array}{l}\text { Serial correl. Test } \\
\text { Top. Inc. endogeneity test }\end{array}$ & 0.378 & $\begin{array}{l}0.700 \\
0.337 \\
\end{array}$ & $\begin{array}{l}0.921 \\
0.311 \\
\end{array}$ & $\begin{array}{l}0.380 \\
0.183 \\
\end{array}$ & $\begin{array}{l}0.809 \\
0.150 \\
\end{array}$ & $\begin{array}{l}0.645 \\
0.186 \\
\end{array}$ \\
\hline
\end{tabular}


Table 3: Baseline regression on effective average tax rates (balanced sample)

\begin{tabular}{|c|c|c|c|c|c|c|}
\hline & \multicolumn{2}{|c|}{$\begin{array}{l}\text { Model without tax } \\
\text { interactions }\end{array}$} & \multicolumn{4}{|c|}{ Model with tax interactions } \\
\hline & {$[1]$} & {$[2]$} & $\begin{array}{c}{[3]} \\
\text { Relative } \\
\text { population } \\
\text { matrix }\end{array}$ & $\begin{array}{c}\text { [4] } \\
\text { Trade } \\
\text { phiness } \\
\text { matrix }\end{array}$ & $\begin{array}{c}5] \\
\text { Distance } \\
\text { matrix }\end{array}$ & $\begin{array}{c}6] \\
\text { FDI matrix }\end{array}$ \\
\hline Lagged tax of country $i$ & & $\begin{array}{c}0.777 * * * \\
(0.035)\end{array}$ & $\begin{array}{c}0.804 * * * \\
(0.035)\end{array}$ & $\begin{array}{c}0.773 * * * \\
(0.035)\end{array}$ & $\begin{array}{c}0.778 * * * \\
(0.036)\end{array}$ & $\begin{array}{c}0.779 * * * \\
(0.042)\end{array}$ \\
\hline $\begin{array}{l}\text { Average tax of other } \\
\text { countries }\end{array}$ & & & $\begin{array}{c}0.794 * * \\
(0.343)\end{array}$ & $\begin{array}{c}0.001 \\
(0.240)\end{array}$ & $\begin{array}{c}0.053 \\
(0.277)\end{array}$ & $\begin{array}{l}0.277 * \\
(0.157)\end{array}$ \\
\hline Real market potential & $\begin{array}{l}0.480 * \\
(0.285)\end{array}$ & $\begin{array}{r}0.227 * * * \\
(0.060)\end{array}$ & $\begin{array}{r}0.247 * * * \\
(0.056)\end{array}$ & $\begin{array}{c}0.232 * * * \\
(0.072)\end{array}$ & $\begin{array}{c}0.231 * * * \\
(0.072)\end{array}$ & $\begin{array}{c}0.276^{* * * *} \\
(0.081)\end{array}$ \\
\hline Top income tax rate & $\begin{array}{c}0.180 * * * \\
(0.061)\end{array}$ & $\begin{array}{c}0.069 * * * \\
(0.024)\end{array}$ & $\begin{array}{l}0.045^{* *} \\
(0.019)\end{array}$ & $\begin{array}{l}0.067 * * \\
(0.033)\end{array}$ & $\begin{array}{l}0.066^{* *} \\
(0.030)\end{array}$ & $\begin{array}{l}0.052 * * \\
(0.025)\end{array}$ \\
\hline Proportion old & $\begin{array}{l}-0.004 \\
(0.004)\end{array}$ & $\begin{array}{c}-0.003 * * \\
(0.001)\end{array}$ & $\begin{array}{c}-0.004 * * * \\
(0.001)\end{array}$ & $\begin{array}{c}-0.003 * * \\
(0.001)\end{array}$ & $\begin{array}{c}-0.003 * * \\
(0.001)\end{array}$ & $\begin{array}{c}-0.003 * * \\
(0.001)\end{array}$ \\
\hline Proportion young & $\begin{array}{c}-0.016^{* * *} \\
(0.005)\end{array}$ & $\begin{array}{c}-0.005^{* * *} \\
(0.001)\end{array}$ & $\begin{array}{c}-0.005^{* * *} \\
(0.001)\end{array}$ & $\begin{array}{c}-0.005^{* * *} \\
(0.001)\end{array}$ & $\begin{array}{c}-0.005^{* * *} \\
(0.001)\end{array}$ & $\begin{array}{c}-0.005^{* * * *} \\
(0.001)\end{array}$ \\
\hline Proportion urban & $\begin{array}{l}-0.001 \\
(0.003)\end{array}$ & $\begin{array}{l}0.001 * \\
(0.001)\end{array}$ & $\begin{array}{l}0.001 * * \\
(0.001)\end{array}$ & $\begin{array}{c}0.001 \\
(0.001)\end{array}$ & $\begin{array}{l}0.001 * \\
(0.001)\end{array}$ & $\begin{array}{c}0.001 \\
(0.001)\end{array}$ \\
\hline Public consumption/GDP & $\begin{array}{c}-0.009 * * * \\
(0.003)\end{array}$ & $\begin{array}{c}-0.003^{* * *} \\
(0.001)\end{array}$ & $\begin{array}{c}-0.003^{* * *} \\
(0.001)\end{array}$ & $\begin{array}{c}-0.003 * * * \\
(0.001)\end{array}$ & $\begin{array}{c}-0.003 * * \\
(0.001)\end{array}$ & $\begin{array}{c}-0.003^{* *} \\
(0.001)\end{array}$ \\
\hline GDR growth & $\begin{array}{l}-0.000 \\
(0.001)\end{array}$ & $\begin{array}{l}-0.001 \\
(0.001)\end{array}$ & $\begin{array}{l}-0.001 \\
(0.001)\end{array}$ & $\begin{array}{l}-0.001 \\
(0.001)\end{array}$ & $\begin{array}{l}-0.001 \\
(0.001)\end{array}$ & $\begin{array}{l}-0.001 \\
(0.001)\end{array}$ \\
\hline Right & $\begin{array}{c}0.030 \\
(0.030)\end{array}$ & $\begin{array}{c}0.008 \\
(0.011)\end{array}$ & $\begin{array}{c}0.007 \\
(0.011)\end{array}$ & $\begin{array}{c}0.009 \\
(0.013)\end{array}$ & $\begin{array}{c}0.009 \\
(0.012)\end{array}$ & $\begin{array}{c}0.010 \\
(0.013)\end{array}$ \\
\hline Right*Majority & $\begin{array}{l}-0.026 \\
(0.050)\end{array}$ & $\begin{array}{c}0.007 \\
(0.018)\end{array}$ & $\begin{array}{c}0.007 \\
(0.016)\end{array}$ & $\begin{array}{c}0.007 \\
(0.021)\end{array}$ & $\begin{array}{c}0.006 \\
(0.020)\end{array}$ & $\begin{array}{c}0.004 \\
(0.021)\end{array}$ \\
\hline Left*Majority & $\begin{array}{c}0.013 \\
(0.022)\end{array}$ & $\begin{array}{c}0.021 * * \\
(0.009)\end{array}$ & $\begin{array}{l}0.017 * \\
(0.010)\end{array}$ & $\begin{array}{l}0.021 * * \\
(0.009)\end{array}$ & $\begin{array}{c}0.020 * * \\
(0.010)\end{array}$ & $\begin{array}{l}0.022 * * \\
(0.009)\end{array}$ \\
\hline EU & $\begin{array}{c}-0.053 * * * \\
(0.019)\end{array}$ & $\begin{array}{c}0.006 \\
(0.006)\end{array}$ & $\begin{array}{c}0.007 \\
(0.005)\end{array}$ & $\begin{array}{c}0.007 \\
(0.006)\end{array}$ & $\begin{array}{c}0.007 \\
(0.006)\end{array}$ & $\begin{array}{c}0.007 \\
(0.006)\end{array}$ \\
\hline Trend & $\begin{array}{c}-0.005^{* * *} \\
(0.001)\end{array}$ & $\begin{array}{c}-0.001 * * * \\
(0.000)\end{array}$ & $\begin{array}{c}0.001 \\
(0.001)\end{array}$ & $\begin{array}{l}-0.001 \\
(0.001)\end{array}$ & $\begin{array}{l}-0.001 \\
(0.001)\end{array}$ & $\begin{array}{l}-0.000 \\
(0.001)\end{array}$ \\
\hline Country dummies & yes & yes & yes & yes & yes & yes \\
\hline Hansen test (p-val) & & 0.366 & 0.969 & 0.894 & 0.574 & 0.191 \\
\hline K-P-under (p-val) & & 0.000 & 0.002 & 0.022 & 0.024 & 0.000 \\
\hline Observations & 450 & 414 & 414 & 399 & 414 & 414 \\
\hline R-squared & 0.59 & 0.84 & 0.83 & 0.84 & 0.84 & 0.84 \\
\hline $\begin{array}{l}\text { Serial correl. Test } \\
\text { Top. Inc. endogeneity test }\end{array}$ & 0.241 & $\begin{array}{l}0.137 \\
0.313\end{array}$ & $\begin{array}{l}0.098 \\
0.667\end{array}$ & $\begin{array}{l}0.154 \\
0.480\end{array}$ & $\begin{array}{l}0.112 \\
0.506\end{array}$ & $\begin{array}{l}0.389 \\
0.146\end{array}$ \\
\hline
\end{tabular}


Table 4: Baseline regression on effective average tax rates (Europe sample)

\begin{tabular}{|c|c|c|c|c|c|c|}
\hline & \multicolumn{2}{|c|}{$\begin{array}{l}\text { Model without tax } \\
\text { interactions }\end{array}$} & \multicolumn{4}{|c|}{ Model with tax interactions } \\
\hline & {$[1]$} & {$[2]$} & $\begin{array}{c}{[3]} \\
\text { Relative } \\
\text { population } \\
\text { matrix }\end{array}$ & $\begin{array}{c}{[4]} \\
\text { Trade } \\
\text { phiness } \\
\text { matrix }\end{array}$ & $\begin{array}{c}5] \\
\text { Distance } \\
\text { matrix }\end{array}$ & $\begin{array}{c}6] \\
\text { FDI matrix }\end{array}$ \\
\hline Lagged tax & & $\begin{array}{c}0.759 * * * \\
(0.034)\end{array}$ & $\begin{array}{c}0.773 * * * \\
(0.034)\end{array}$ & $\begin{array}{c}0.750^{* * *} \\
(0.044)\end{array}$ & $\begin{array}{c}0.776^{* * *} \\
(0.036)\end{array}$ & $\begin{array}{c}0.769 * * * \\
(0.036)\end{array}$ \\
\hline $\begin{array}{l}\text { Average tax of other } \\
\text { countries }\end{array}$ & & & $\begin{array}{l}0.488^{*} \\
(0.282)\end{array}$ & $\begin{array}{l}0.283^{*} \\
(0.169)\end{array}$ & $\begin{array}{l}0.246^{*} \\
(0.141)\end{array}$ & $\begin{array}{c}0.378 \\
(0.404)\end{array}$ \\
\hline Real market potential & $\begin{array}{c}1.121^{*} \\
(0.579)^{*}\end{array}$ & $\begin{array}{c}0.268 * * * \\
(0.094)\end{array}$ & $\begin{array}{c}0.323 * * * \\
(0.101)\end{array}$ & $\begin{array}{c}0.365^{* * *} \\
(0.094)\end{array}$ & $\begin{array}{c}0.239 * * \\
(0.095)\end{array}$ & $\begin{array}{c}0.311 * * * \\
(0.106)\end{array}$ \\
\hline Top income tax rate & $\begin{array}{l}0.143^{*} \\
(0.080)\end{array}$ & $\begin{array}{c}0.046 \\
(0.028)\end{array}$ & $\begin{array}{c}0.030 \\
(0.027)\end{array}$ & $\begin{array}{c}0.032 \\
(0.033)\end{array}$ & $\begin{array}{c}0.044 \\
(0.030)\end{array}$ & $\begin{array}{c}0.040 \\
(0.033)\end{array}$ \\
\hline Proportion old & $\begin{array}{l}-0.007 \\
(0.006)\end{array}$ & $\begin{array}{c}-0.005 * * * \\
(0.002)\end{array}$ & $\begin{array}{c}-0.006 * * * \\
(0.002)\end{array}$ & $\begin{array}{c}-0.006^{* * *} \\
(0.002)\end{array}$ & $\begin{array}{c}-0.006^{* * *} \\
(0.002)\end{array}$ & $\begin{array}{c}-0.005^{* * *} \\
(0.002)\end{array}$ \\
\hline Proportion young & $\begin{array}{c}-0.011 * * \\
(0.005)\end{array}$ & $\begin{array}{c}-0.004 * * * \\
(0.001)\end{array}$ & $\begin{array}{c}-0.004 * * * \\
(0.001)\end{array}$ & $\begin{array}{c}-0.003 * * * \\
(0.001)\end{array}$ & $\begin{array}{c}-0.003 * * * \\
(0.001)\end{array}$ & $\begin{array}{c}-0.003 * * * \\
(0.001)\end{array}$ \\
\hline Proportion urban & $\begin{array}{l}-0.001 \\
(0.003)\end{array}$ & $\begin{array}{c}0.001 \\
(0.001)\end{array}$ & $\begin{array}{c}0.001 \\
(0.001)\end{array}$ & $\begin{array}{c}0.001 \\
(0.001)\end{array}$ & $\begin{array}{c}0.001 \\
(0.001)\end{array}$ & $\begin{array}{c}0.001 \\
(0.001)\end{array}$ \\
\hline Public consumption/GDP & $\begin{array}{l}-0.004 \\
(0.003)\end{array}$ & $\begin{array}{l}-0.002 * \\
(0.001)\end{array}$ & $\begin{array}{l}-0.002 \\
(0.001)\end{array}$ & $\begin{array}{l}-0.002 \\
(0.001)\end{array}$ & $\begin{array}{l}-0.002 \\
(0.001)\end{array}$ & $\begin{array}{l}-0.002 * \\
(0.001)\end{array}$ \\
\hline GDR growth & $\begin{array}{l}-0.001 \\
(0.001)\end{array}$ & $\begin{array}{c}0.000 \\
(0.001)\end{array}$ & $\begin{array}{l}-0.000 \\
(0.001)\end{array}$ & $\begin{array}{l}-0.000 \\
(0.001)\end{array}$ & $\begin{array}{c}0.000 \\
(0.001)\end{array}$ & $\begin{array}{c}0.000 \\
(0.001)\end{array}$ \\
\hline Right & $\begin{array}{c}0.007 \\
(0.035)\end{array}$ & $\begin{array}{c}-0.003 \\
(0.012)\end{array}$ & $\begin{array}{c}-0.004 \\
(0.012)\end{array}$ & $\begin{array}{l}-0.004 \\
(0.012)\end{array}$ & $\begin{array}{c}-0.003 \\
(0.013)\end{array}$ & $\begin{array}{l}-0.005 \\
(0.013)\end{array}$ \\
\hline Right*Majority & $\begin{array}{c}0.032 \\
(0.056)\end{array}$ & $\begin{array}{c}0.033^{*} \\
(0.018)\end{array}$ & $\begin{array}{l}0.032 * \\
(0.017)\end{array}$ & $\begin{array}{l}0.035^{*} \\
(0.018)\end{array}$ & $\begin{array}{l}0.033^{*} \\
(0.019)\end{array}$ & $\begin{array}{c}0.038^{*} \\
(0.021)\end{array}$ \\
\hline Left*Majority & $\begin{array}{c}0.022 \\
(0.033)\end{array}$ & $\begin{array}{c}0.023 * * \\
(0.011)\end{array}$ & $\begin{array}{l}0.020^{*} \\
(0.011)\end{array}$ & $\begin{array}{l}0.021^{*} \\
(0.011)\end{array}$ & $\begin{array}{l}0.021^{*} \\
(0.012)\end{array}$ & $\begin{array}{c}0.024 * * \\
(0.010)\end{array}$ \\
\hline EU & $\begin{array}{c}-0.056 * * * \\
(0.016)\end{array}$ & $\begin{array}{c}-0.004 \\
(0.007)\end{array}$ & $\begin{array}{c}-0.004 \\
(0.007)\end{array}$ & $\begin{array}{c}0.001 \\
(0.006)\end{array}$ & $\begin{array}{c}-0.000 \\
(0.007)\end{array}$ & $\begin{array}{c}-0.004 \\
(0.007)\end{array}$ \\
\hline Trend & $\begin{array}{c}-0.005 * * * \\
(0.001)\end{array}$ & $\begin{array}{c}-0.001 * * \\
(0.000)\end{array}$ & $\begin{array}{c}0.001 \\
(0.001)\end{array}$ & $\begin{array}{c}0.000 \\
(0.001)\end{array}$ & $\begin{array}{c}0.001 \\
(0.001)\end{array}$ & $\begin{array}{c}0.001 \\
(0.002)\end{array}$ \\
\hline Country dummies & yes & yes & yes & yes & Yes & Yes \\
\hline Hansen test ( $p$-val) & & 0.283 & 0.669 & 0.547 & 0.550 & 0.507 \\
\hline K-P-under (p-val) & & 0.000 & 0.002 & 0.001 & 0.114 & 0.000 \\
\hline Observations & 445 & 409 & 409 & 394 & 409 & 409 \\
\hline R-squared & 0.51 & 0.82 & 0.82 & 0.82 & 0.82 & 0.82 \\
\hline $\begin{array}{l}\text { Serial correl. Test } \\
\text { Top. Inc. endogeneity test }\end{array}$ & 0.260 & $\begin{array}{l}0.697 \\
0.617\end{array}$ & $\begin{array}{l}0.436 \\
0.994\end{array}$ & $\begin{array}{l}0.403 \\
0.453\end{array}$ & $\begin{array}{l}0.697 \\
0.626\end{array}$ & $\begin{array}{l}0.950 \\
0.505\end{array}$ \\
\hline
\end{tabular}


Table 5: Baseline regression on effective marginal tax rates (unbalanced sample)

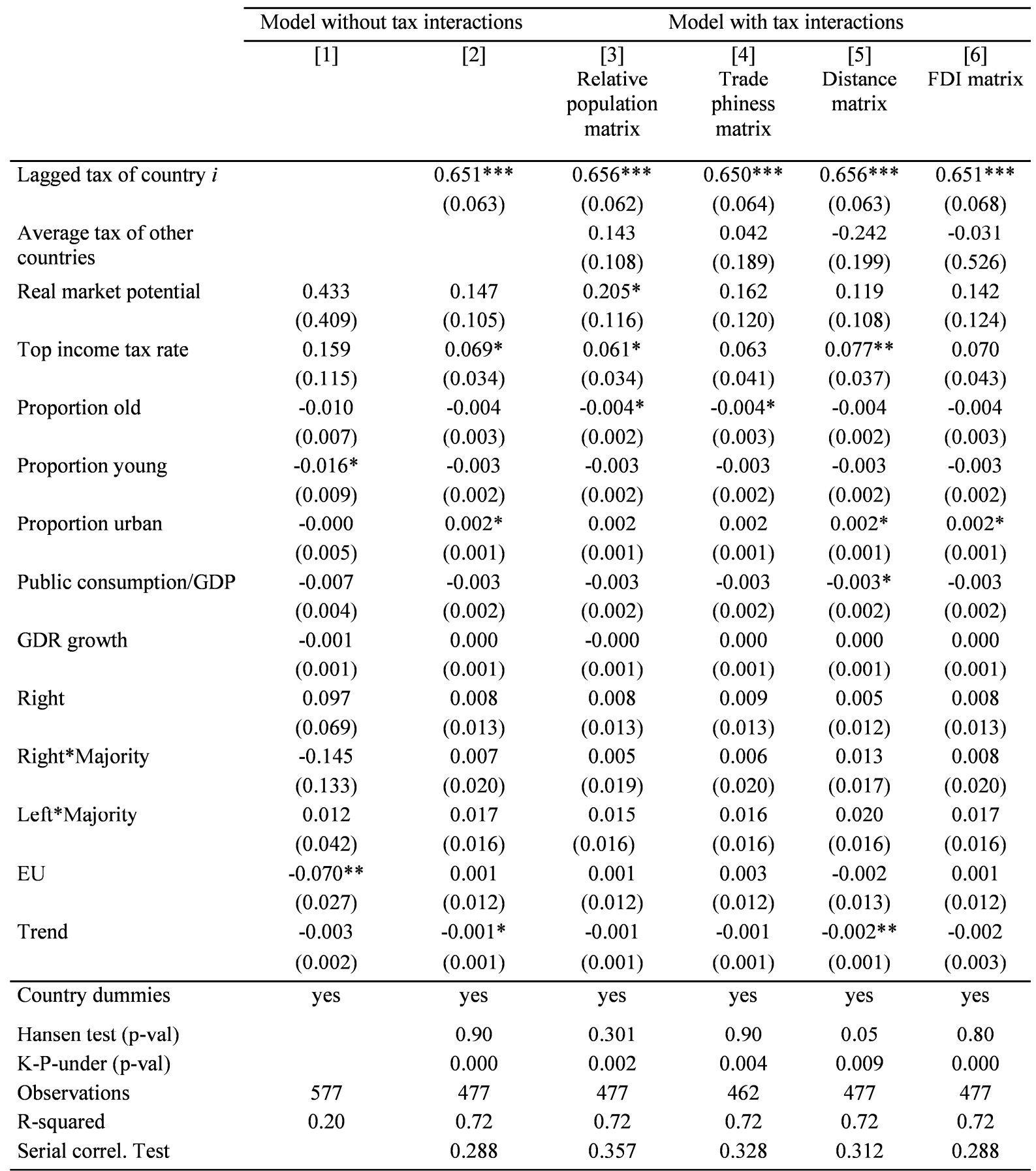

Estimations on an unbalanced sample of 26 countries over the period 1982-2006. Dependent variable, Effective marginal tax rates. Parentheses contain standard errors robust to serial correlation and heteroscedasticity. Significance levels: * $10 \%, * * 5 \%$ and $* * * 1 \%$. 
Table 6: Baseline regression on statutory tax rates (unbalanced sample)

\begin{tabular}{|c|c|c|c|c|c|c|}
\hline & \multicolumn{2}{|c|}{$\begin{array}{l}\text { Model without tax } \\
\text { interactions }\end{array}$} & \multicolumn{4}{|c|}{ Model with tax interactions } \\
\hline & {$[1]$} & {$[2]$} & $\begin{array}{c}3] \\
\text { Relative } \\
\text { population } \\
\text { matrix }\end{array}$ & $\begin{array}{c}4] \\
\text { Trade } \\
\text { phiness } \\
\text { matrix }\end{array}$ & $\begin{array}{c}5] \\
\text { Distance } \\
\text { matrix }\end{array}$ & $\begin{array}{c}6] \\
\text { FDI matrix }\end{array}$ \\
\hline Lagged tax of country $i$ & & $\begin{array}{c}0.733 * * * \\
(0.036)\end{array}$ & $\begin{array}{c}0.729 * * * \\
(0.046)\end{array}$ & $\begin{array}{c}0.666^{* * * *} \\
(0.047)\end{array}$ & $\begin{array}{c}0.742 * * * \\
(0.035)\end{array}$ & $\begin{array}{c}0.733 * * * \\
(0.037)\end{array}$ \\
\hline $\begin{array}{l}\text { Average tax of other } \\
\text { countries }\end{array}$ & & & $\begin{array}{l}0.499 * * \\
(0.204)\end{array}$ & $\begin{array}{c}0.516 * * \\
(0.223)\end{array}$ & $\begin{array}{c}0.466 \\
(0.568)\end{array}$ & $\begin{array}{c}0.107 \\
(0.170)\end{array}$ \\
\hline Real market potential & $\begin{array}{c}0.907 * * * \\
(0.306)\end{array}$ & $\begin{array}{c}0.419 * * * \\
(0.088)\end{array}$ & $\begin{array}{c}0.521^{* * * *} \\
(0.092)\end{array}$ & $\begin{array}{c}0.618 * * * \\
(0.149)\end{array}$ & $\begin{array}{c}0.466 * * * \\
(0.127)\end{array}$ & $\begin{array}{c}0.453 * * * \\
(0.113)\end{array}$ \\
\hline Top income tax rate & $\begin{array}{c}0.210 * * * \\
(0.056)\end{array}$ & $\begin{array}{c}0.087 * * * \\
(0.032)\end{array}$ & $\begin{array}{c}0.063 * * \\
(0.031)\end{array}$ & $\begin{array}{c}0.038 \\
(0.033)\end{array}$ & $\begin{array}{c}0.054 \\
(0.043)\end{array}$ & $\begin{array}{c}0.081 * * * \\
(0.031)\end{array}$ \\
\hline Proportion old & $\begin{array}{l}-0.005 \\
(0.005)\end{array}$ & $\begin{array}{l}-0.001 \\
(0.002)\end{array}$ & $\begin{array}{c}-0.004 * * \\
(0.002)\end{array}$ & $\begin{array}{l}-0.004 * \\
(0.002)\end{array}$ & $\begin{array}{l}-0.002 \\
(0.002)\end{array}$ & $\begin{array}{l}-0.001 \\
(0.002)\end{array}$ \\
\hline Proportion young & $\begin{array}{c}-0.017 * * * \\
(0.006)\end{array}$ & $\begin{array}{l}-0.004 * \\
(0.002)\end{array}$ & $\begin{array}{c}-0.005 * * \\
(0.003)\end{array}$ & $\begin{array}{l}-0.005 * * \\
(0.002)\end{array}$ & $\begin{array}{l}-0.002 \\
(0.003)\end{array}$ & $\begin{array}{l}-0.004 * \\
(0.002)\end{array}$ \\
\hline Proportion urban & $\begin{array}{l}0.004 * \\
(0.003)\end{array}$ & $\begin{array}{l}0.002 * * \\
(0.001)\end{array}$ & $\begin{array}{c}0.003 * * * \\
(0.001)\end{array}$ & $\begin{array}{l}0.002 * \\
(0.001)\end{array}$ & $\begin{array}{c}0.002 \\
(0.001)\end{array}$ & $\begin{array}{l}0.002 * * \\
(0.001)\end{array}$ \\
\hline $\begin{array}{l}\text { Public } \\
\text { consumption/GDP }\end{array}$ & $\begin{array}{l}-0.005 \\
(0.003)\end{array}$ & $\begin{array}{c}-0.003 * * \\
(0.001)\end{array}$ & $\begin{array}{c}-0.003 * * \\
(0.001)\end{array}$ & $\begin{array}{l}-0.003 * \\
(0.001)\end{array}$ & $\begin{array}{c}-0.002 * * \\
(0.001)\end{array}$ & $\begin{array}{c}-0.003 * * \\
(0.001)\end{array}$ \\
\hline GDR growth & $\begin{array}{c}0.000 \\
(0.001)\end{array}$ & $\begin{array}{c}0.001 \\
(0.001)\end{array}$ & $\begin{array}{c}0.000 \\
(0.001)\end{array}$ & $\begin{array}{l}-0.000 \\
(0.001)\end{array}$ & $\begin{array}{c}0.001 \\
(0.001)\end{array}$ & $\begin{array}{c}0.001 \\
(0.001)\end{array}$ \\
\hline Right & $\begin{array}{c}-0.017 \\
(0.032)\end{array}$ & $\begin{array}{c}-0.000 \\
(0.012)\end{array}$ & $\begin{array}{l}-0.001 \\
(0.015)\end{array}$ & $\begin{array}{c}-0.001 \\
(0.014)\end{array}$ & $\begin{array}{l}-0.001 \\
(0.013)\end{array}$ & $\begin{array}{l}-0.000 \\
(0.013)\end{array}$ \\
\hline Right*Majority & $\begin{array}{c}0.077 \\
(0.050)\end{array}$ & $\begin{array}{c}0.026 \\
(0.018)\end{array}$ & $\begin{array}{c}0.020 \\
(0.021)\end{array}$ & $\begin{array}{c}0.017 \\
(0.018)\end{array}$ & $\begin{array}{c}0.024 \\
(0.018)\end{array}$ & $\begin{array}{c}0.026 \\
(0.019)\end{array}$ \\
\hline Left*Majority & $\begin{array}{c}0.033 \\
(0.033)\end{array}$ & $\begin{array}{c}0.020 \\
(0.014)\end{array}$ & $\begin{array}{c}0.013 \\
(0.017)\end{array}$ & $\begin{array}{c}0.010 \\
(0.016)\end{array}$ & $\begin{array}{c}0.015 \\
(0.016)\end{array}$ & $\begin{array}{c}0.020 \\
(0.014)\end{array}$ \\
\hline EU & $\begin{array}{c}-0.074 * * * \\
(0.014)\end{array}$ & $\begin{array}{c}-0.007 \\
(0.005)\end{array}$ & $\begin{array}{c}-0.011^{*} \\
(0.006)\end{array}$ & $\begin{array}{c}-0.002 \\
(0.007)\end{array}$ & $\begin{array}{c}0.003 \\
(0.016)\end{array}$ & $\begin{array}{c}-0.007 \\
(0.005)\end{array}$ \\
\hline Trend & $\begin{array}{c}-0.009 * * * \\
(0.001)\end{array}$ & $\begin{array}{c}-0.002 * * * \\
(0.001)\end{array}$ & $\begin{array}{c}0.001 \\
(0.002)\end{array}$ & $\begin{array}{c}0.001 \\
(0.002)\end{array}$ & $\begin{array}{c}0.002 \\
(0.005)\end{array}$ & $\begin{array}{l}-0.001 \\
(0.001)\end{array}$ \\
\hline Country dummies & yes & yes & yes & yes & yes & yes \\
\hline Hansen test (p-val) & & 0.110 & 0.800 & 0.723 & 0.208 & 0.175 \\
\hline K-P-under (p-val) & & 0.000 & 0.000 & 0.003 & 0.516 & 0.000 \\
\hline Observations & 591 & 521 & 546 & 531 & 521 & 521 \\
\hline R-squared & 0.64 & 0.85 & 0.85 & 0.85 & 0.85 & 0.85 \\
\hline Serial correl. Test & & 0.438 & 0.188 & 0.337 & 0.710 & 0.443 \\
\hline
\end{tabular}

Estimations on an unbalanced sample of 26 countries over the period 1982-2006. Dependent variable, Statutory tax rates. Parentheses contain standard errors robust to serial correlation and heteroscedasticity. Significance levels: $* 10 \%, * * 5 \%$ and $* * * 1 \%$. 
Table 7: Extended regression on effective average tax rates (unbalanced sample)

\begin{tabular}{lcccc}
\cline { 2 - 5 } & $\begin{array}{c}{[3]} \\
\text { Relative } \\
\text { population } \\
\text { matrix }\end{array}$ & $\begin{array}{c}\text { Trade } \\
\text { phiness } \\
\text { matrix }\end{array}$ & $\begin{array}{c}{[5]} \\
\text { Distance matrix }\end{array}$ & $\begin{array}{c}{[6]} \\
\text { FDI } \\
\text { matrix }\end{array}$ \\
\hline Lagged tax of country $i$ & $0.759^{* * *}$ & $0.741^{* * *}$ & $0.767^{* * *}$ & $0.728^{* * *}$ \\
$O_{i} \bar{\tau}_{-i, t}^{O}$ & $(0.036)$ & $(0.048)$ & $(0.044)$ & $(0.038)$ \\
$O_{i} \bar{\tau}_{-i, t}$ & $0.457^{*}$ & $0.240^{*}$ & 0.147 & -0.015 \\
$\left(1-O_{i}\right) \bar{\tau}_{-i, t}^{O}$ & $(0.276)$ & $(0.125)$ & $(0.151)$ & $(0.106)$ \\
& 0.240 & -0.371 & 0.011 & 0.086 \\
$\left(1-O_{i}\right) \bar{\tau}_{-i, t}^{C}$ & $(0.216)$ & $(0.284)$ & $(0.148)$ & $(0.173)$ \\
& $0.723 *$ & -0.345 & -0.188 & 0.147 \\
Control variables & $(0.423)$ & $(0.237)$ & $(0.253)$ & $(0.176)$ \\
Country dummies & 0.123 & 0.103 & 0.226 & 0.077 \\
Hansen test (p-val) & $(0.307)$ & $(0.295)$ & $(0.169)$ & $(0.182)$ \\
K-P-under (p-val) & yes & yes & yes & yes \\
Observations & yes & yes & yes & yes \\
R-squared & 0.452 & 0.142 & 0.427 & 0.516 \\
\hline Estmations on an & 0.000 & 0.100 & 0.056 & 0.000 \\
& 529 & 514 & 529 & 529 \\
& 0.67 & 0.60 & 0.64 & 0.65 \\
\hline
\end{tabular}

Estimations on an unbalanced sample of 26 countries over the period 1982-2006. Dependent variable, Effective average tax rates. Parentheses contain standard errors robust to serial correlation and heteroscedasticity. Significance levels: $* 10 \%, * * 5 \%$ and $* * * 1 \%$. 